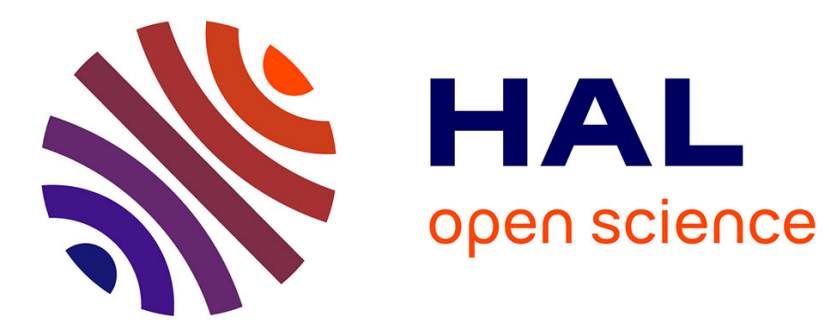

\title{
Ion-Imprinted Nanofilms Based on Tannic Acid and Silver Nanoparticles for Sensing of Al(III)
}

\author{
Agata Krywko-Cendrowska, Laurent Marot, Daniel Mathys, Fouzia \\ Boulmedais
}

\section{- To cite this version: \\ Agata Krywko-Cendrowska, Laurent Marot, Daniel Mathys, Fouzia Boulmedais. Ion-Imprinted Nanofilms Based on Tannic Acid and Silver Nanoparticles for Sensing of Al(III). ACS Applied Nano Materials, In press, 10.1021/acsanm.1c00716 . hal-03229521}

\section{HAL Id: hal-03229521 \\ https://hal.science/hal-03229521}

Submitted on 19 May 2021

HAL is a multi-disciplinary open access archive for the deposit and dissemination of scientific research documents, whether they are published or not. The documents may come from teaching and research institutions in France or abroad, or from public or private research centers.
L'archive ouverte pluridisciplinaire $\mathbf{H A L}$, est destinée au dépôt et à la diffusion de documents scientifiques de niveau recherche, publiés ou non, émanant des établissements d'enseignement et de recherche français ou étrangers, des laboratoires publics ou privés. 


\section{Ion-Imprinted Nanofilms Based on Tannic Acid and Silver Nanoparticles for Sensing of Al(III)}

Agata Krywko-Cendrowska ${ }^{1 \dagger^{* *}}$, Laurent Marot $^{2}$, Daniel Mathys $^{3}$, Fouzia Boulmedais ${ }^{1 *}$

${ }^{1}$ University of Strasbourg, CNRS, Institut Charles Sadron UPR 22, 67034 Strasbourg, France ${ }^{2}$ Department of Physics, University of Basel, Klingelbergstrasse 82, CH-4056 Basel, Switzerland ${ }^{3}$ Swiss Nanoscience Institute, University of Basel, Klingelbergstrasse 50/70, CH-4056 Basel, Switzerland

corresponding authors: a.krywko@unibas.ch; fouzia.boulmedais@ics-cnrs.unistra.fr

Keywords: supramolecular film, electrochemical self-assembly, aluminum sensing, ionprinting, tailored sensor, human serum, electro-cross-linking 
Abstract: Electrochemically triggered self-assembly can be effectively utilized to produce electroactive materials of tailored properties for various applications, such as sensor development. Here, we present a thin sensor film based on tannic acid (TA) and silver nanoparticles (AgNPs), ionically imprinted via electrodeposition and tailor-designed for electrochemical tracing of aluminum ions, $\mathrm{Al}(\mathrm{III})$. In the first stage, the conditions for the $\mathrm{Al}$ (III)-printing of TA films onto indium-tin-oxide (ITO) electrode via electrodeposition are established and optimized. To form an AgNPs-containing film, AgNPs are presynthesized via a direct reduction of $\operatorname{Ag}(\mathrm{I})$ by TA resulting in TA-stabilized AgNPs (TA@AgNPs) of 1-4 nm in size, as observed by dynamic light scattering. Next, $\mathrm{Al}(\mathrm{III})$ ions are added to complex the TA molecules adsorbed on the surface of AgNPs. The resulting Al(III)/TA@AgNPs mixture is then electrodeposited onto ITO surface by applying an anodic potential to form a film. As a result a mesh-structured layer composed of AgNPs with TA on their surface and electrochemically cross-linked via TA-TA covalent bonds at the $\mathrm{Al}(\mathrm{III})$-free coordination sites is formed. The introduction of $\mathrm{Al}(\mathrm{III})$ ions bonded via coordination bonds with $\mathrm{TA}$ and their consecutive removal using sodium fluoride formed vacancies ready to bind $\mathrm{Al}(\mathrm{III})$ ions from the analyzed solution allowing their electrochemical sensing, as monitored by cyclic voltammetry, quartz crystal microbalance (QCM) and X-ray photoelectron spectroscopy. The film was employed for sensing of neurotoxic $\mathrm{Al}(\mathrm{III})$ in human serum. A linear correlation between the current value at $0.9 \mathrm{~V}$ and the concentration of $\mathrm{Al}(\mathrm{III})$ was obtained in the range between 0.10 and $0.298 \mu \mathrm{M}$. 
Graphical abstract

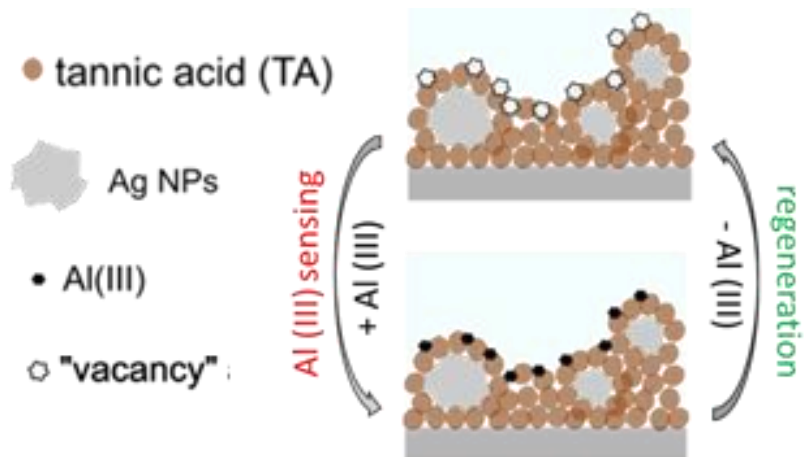




\section{Introduction}

Self-assembly technique is playing an important role in preparing well-defined multilevel nanostructures and the functionalized nanomaterials of designed and controlled properties. ${ }^{1}$ Molecular self-assembly usually takes advantage of supramolecular interactions (ionic, hydrophobic, van der Waals, hydrogen and coordination bonds), but can also make use of kinetically labile covalent bonds ${ }^{2}$ or redox processes triggered by an electrical stimulus ${ }^{3}$. Electrochemically triggered self-construction of films is a relatively simple, promising and effective approach (i) providing covalent ${ }^{4-6}$ and/or (ii) non-covalent ${ }^{4,7,8}$ immobilization of compounds with excellent functionalities ${ }^{9}$ or (bio)-activities ${ }^{4,10}$ and (iii) allowing selective functionalization of microelectrode arrays., ${ }^{4,}, 10$

Polyphenols, such as tannic acid, TA, are able to coordinate and to self-assemble with different metal ions into combined cross-linked networks of polyphenols and metal ions, the functionality of which can be versatile based on the incorporated polyphenols and metal ions ${ }^{11-}$ 13. Tannic acid, the polyphenol used in this work, is present in abundance in nature and easily accessible. It can also act as a reducing or stabilizing agent to form metal nanoparticles ${ }^{14}$ by reacting covalently in its oxidative state forming intermolecular bonds leading to the formation of a film. The ability of TA to form covalent bonds between its own molecules under an electrical stimulus, as well as its ability to complex metals like iron, vanadium or aluminum to form electroactive nanocoatings ${ }^{15}$ can be very well utilized for the fabrication of an electrochemical sensor, using, for example, a molecular imprinting ${ }^{16}$ or an ion-printing approach $^{17,18}$ and introduction of metal nanoparticles. ${ }^{19}$

Herein, an electrochemically triggered self-assembly approach was utilized to produce metalpolyphenol thin films tailor-designed for voltammetric sensing of aluminum, $\mathrm{Al}(\mathrm{III})$, via an ionprinting approach. Aluminum is widely used in almost every area of our everyday life, i.e. from food processing, water purification, cosmetics, medicines, vaccinations to clothing and building 
construction, due to its incredibly useful physicochemical properties. On the other hand, Al(III), even at a trace level in biological fluids, is a dangerous neurotoxin with poisoning effects. It binds to the phosphate groups of DNA and RNA, influencing their topology, affects gene transcription and accumulates in the brain matter. ${ }^{20-22}$ Currently, the determination of $\mathrm{Al}(\mathrm{III})$ levels in biological fluids of patients is conventionally performed using laboratory-based spectroscopic methods, ${ }^{23}$ offering reasonable sensitivity and reliability, but requiring expensive instrumentation, expertise in handling and presenting the limitation of an ex-situ analysis. ${ }^{24}$ With its high sensitivity and rapid analysis time, electrochemical determination of $\mathrm{Al}(\mathrm{III})$ level could be ideal for routine monitoring. A range of electrochemical sensors has been reported in the literature, based on enzyme inhibition, ${ }^{25,26}$ different complexing agents of metal ions ${ }^{27,28}$ such as (poly)phenols ${ }^{23,29-33}$ or zeolites. ${ }^{34,35}$ These sensors, however, suffer from different drawbacks: low sensitivity or precision, use of mercury electrodes, sensitivity to interfering

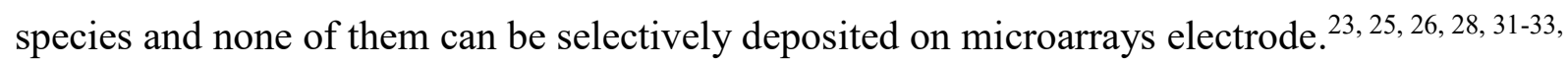
${ }^{36-38}$ Most of them were designed for (i) Al(III) sensing in acidic conditions ${ }^{23,27,28,32-35}$ and/or (ii) in physiological conditions but in the absence of serum proteins. ${ }^{25,26,29}$

Here, we report for the first time an application of electrochemically assisted self-assembly to form a complex supramolecular hybrid thin film composed of a biodegradable and non-toxic molecules, metal ions and metal nanoparticles. The film was obtained via a one pot process while taking advantage of multiple specific supramolecular and chemical interactions of each component of the system such to ensure the tailored properties of the sensor towards electrochemical sensing of $\mathrm{Al}(\mathrm{III})$ in biological fluids. TA has been selected as the suitable monomer candidate for the polymeric matrix of the sensor due to its ability to form relatively stable complexes with $\mathrm{Al}(\mathrm{III})^{15}$ as well as to cross-link under an oxidant stimulus to form a film. ${ }^{3}$ Due to the biological fluids being the targeted medium for the sensing process, the film was deposited onto indium tin oxide (ITO) to ensure the stability of the electrode upon an 
extended contact with a chloride solution as opposed to e.g., gold. ${ }^{39,40}$ Due to the use of a semiconductive substrate and low electrical conductivity of the cross-linked TA, AgNPs were chosen as the next component of the film due to their high electrical conductivity and ability to enhance the electron transfer between the organic coating and the electrode and thus, improving the overall sensitivity of the film. ${ }^{41-43}$ Following, a mussel inspired electro-cross-linking of TAcapped silver nanoparticles (TA@AgNPs) complexed by $\mathrm{Al}(\mathrm{III})$ was utilized to develop ionically imprinted electroactive sensor coatings. A mixture of pre-synthesized TA@AgNPs complexed by $\mathrm{Al}(\mathrm{III})$ was used as a building solution in contact with ITO electrode. The application of an anodic potential induced the oxidation of TA gallol moieties into quinone moieties that led to TA cross-linking and the simultaneous covalent immobilization of TA@AgNP with the incorporation of Al(III) ions through the coordination bonds.

The obtained sensor, based on non-toxic and environmentally friendly and abundant species, was proven to be stable over a longer period of time under a physiological concentration of sodium chloride buffered at $\mathrm{pH} 7.4$ and was applied for $\mathrm{Al}(\mathrm{III})$ sensing in human serum solution. The results provide new insight into complex supramolecular film formation and understanding of the voltammetric sensing of metal ions in blood serum samples as well as stability of AgNPs under physiological conditions. This new electrochemically assisted selfassembly approach could be easily generalized for detection of several metal ions, i.e. by choosing an appropriate type of molecule or macromolecule and metal nanoparticles or adjusting a fitting agent to remove the particular metal ion. ${ }^{44}$ 


\section{Results and discussion}

\subsection{Formation of Al(III)/TA films on ITO}

Initial experiments involved the study on the ability of TA to form films with $\mathrm{Al}(\mathrm{III})$ via electrochemically assisted self-assembly according to the scheme shown in Figure 1, as well as their electrochemical behavior to obtain a reference before involving AgNPs as the film building blocks. The experimental parameters of the electrodeposition were optimized previously where $\mathrm{Fe}(\mathrm{III}) / \mathrm{TA}$ films were deposited using the oxidation of $\mathrm{Fe}(\mathrm{II}) .{ }^{3}$ We noticed that the application of a potential higher than $0.5 \mathrm{~V}$ induces a cross-linking of TA. Following the procedure established, we adjusted the protocol accordingly using the same concentration of TA. As TA can coordinate up to three $\mathrm{Al}(\mathrm{III})$ ions ${ }^{45}$, the $\mathrm{Al}(\mathrm{III})$ to TA molar ratio of 2.5 was chosen for the film formed to both contain a sufficient number of $\mathrm{Al}(\mathrm{III})$ incorporated and also to assure a considerable number of TA free sites available for the TA-TA bonding during the electrochemically triggered self-assembly of the film.

a
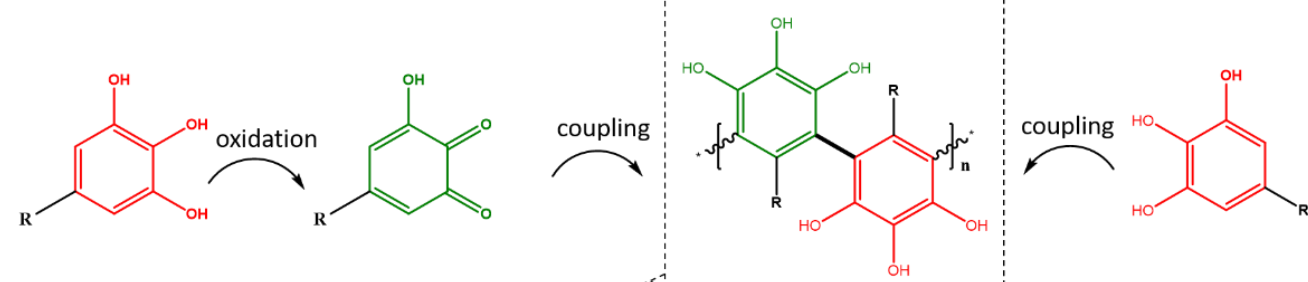

b
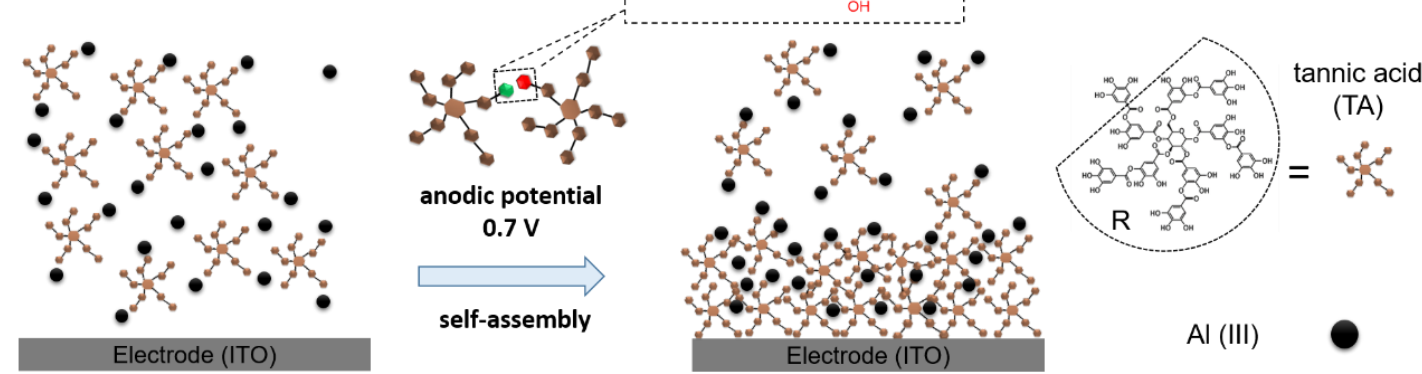

Figure 1 Formation of Al(III)-imprinted film via electrochemically triggered cross-linking of tannic acid molecules complexed by $\mathrm{Al}(\mathrm{III})$; a) mechanism of the TA-TA covalent bond formation upon an electrical stimulus and b) schematic presentation of the self-assembly of the $\mathrm{Al}(\mathrm{III}) / \mathrm{TA}$ film. 
Due to the fact that the properties and physicochemical stability of the TA-based films vary depending on the $\mathrm{pH}$, to ensure the stability of the films under the conditions intended for sensing later on, the self-assembly of the films was performed at the targeted physiological $\mathrm{pH}$ value of 7.4. In the first stage, the electrochemical response of TA and $\mathrm{Al}(\mathrm{III})$ in $0.15 \mathrm{M} \mathrm{KPF}_{6}$ was studied by cyclic voltammetry $(\mathrm{CV})$ to determine the applicable potential range for the selfassembly of the films onto ITO electrode surface. The CV registered for the of TA-Al(III) electrodeposition (ED) mixture (Figure 2a) exhibited an oxidation range between 0.4 and 1.1 $\mathrm{V}$ with a peak centered at $0.9 \mathrm{~V}$ corresponding to the oxidation of TA-Al(III) complexes. In the case of $\mathrm{CV}$ where no $\mathrm{Al}(\mathrm{III})$ was added, the oxidation range of TA was slightly shifted towards the lower potential values in comparison to the Al(III)-TA curve prompting that the crosslinking of the not complexed TA molecules required a lower overpotential than in a complexed state.
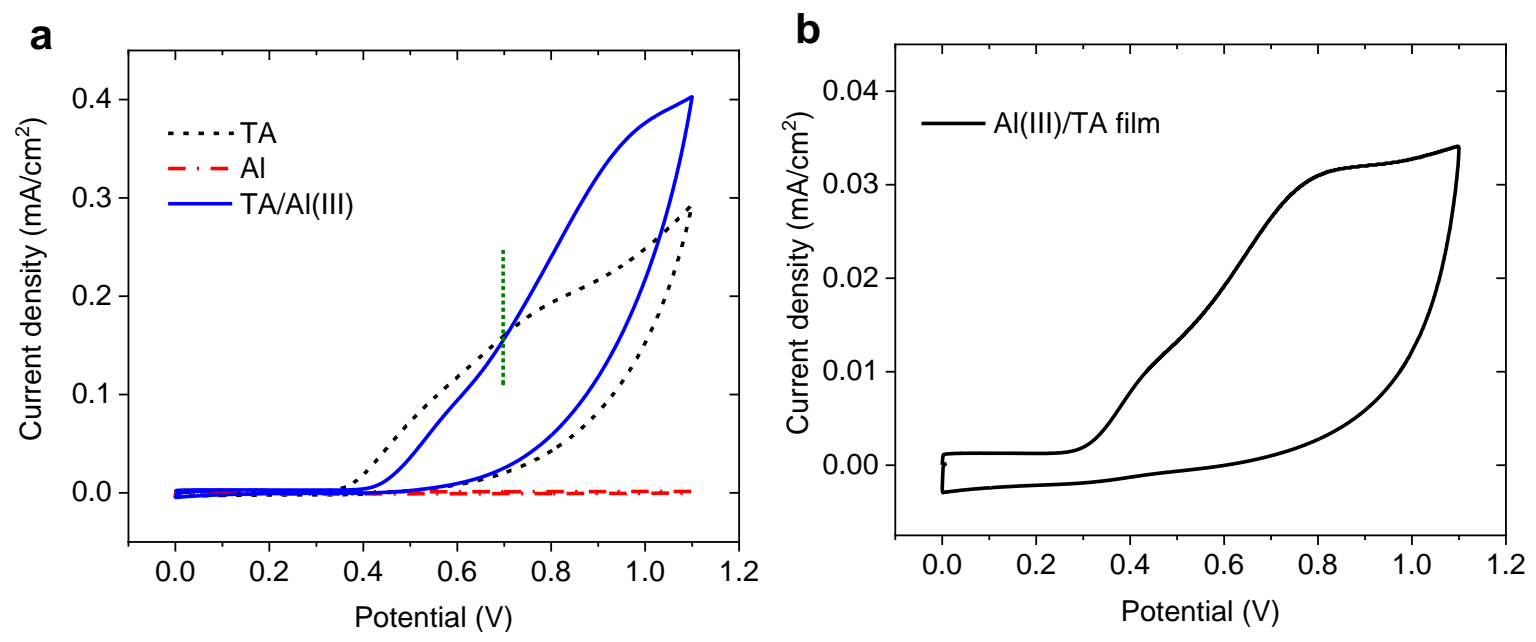

Figure 2 a) Cyclic voltammograms registered for bare ITO electrode in TA and Al(III) solutions at concentrations corresponding to the ED and the Al(III)-TA ED mixture at 2.5 Al(III)/TA molar ratio. b) Cyclic voltammogram of the as-deposited Al(III)-TA film. All curves registered at $50 \mathrm{mV} / \mathrm{s}$ in $0.15 \mathrm{M} \mathrm{KPF}_{6}$ adjusted to $\mathrm{pH}$ 7.4. The ED potential is marked with a dotted line in a). 
In both cases, the oxidation of TA molecules corresponds to the oxidative crosslinking of the TA-TA molecules. In the case of $\mathrm{Al}(\mathrm{III}) / \mathrm{TA}$ complex, a higher activation energy is required to decompose the complex first before the oxidation of TA. The current registered for the Al(III) solution is similar to $0.15 \mathrm{M} \mathrm{KPF}_{6}$ medium. $\mathrm{Al}(\mathrm{III}) / \mathrm{Al}$ has a redox potential at $-1.67 \mathrm{vs} \mathrm{NHE}$ ($1.87 \mathrm{vs} \mathrm{Ag} / \mathrm{AgCl}$ ) which is not in the potential range of the $\mathrm{CV}$. The $\mathrm{CV}$ registered for the bare ITO electrode in a solution containing Al(III) exhibited no distinctive signals and the capacity current measured was of the same magnitude as for the $\mathrm{KPF}_{6}$ solution (Figure $\mathbf{S 1}$ in the SI), showing no influence of $\mathrm{Al}(\mathrm{III})$ on the current value when a non-coated ITO electrode was used. On the basis of the $\mathrm{CV}$ data, the potential value for the potentiostatic electrodeposition was set to $0.7 \mathrm{~V}$, which was high enough to cause the crosslinking between the TA molecules in a complexed state (Figure 2a) and, on the other hand, too low to favor the oxidation and decomposition of TA-Al(III) complexes in the ED solution. The ED current and the quartz crystal microbalance (QCM) curve registered in-situ for the formation of the film are shown in Figure $\mathbf{S} 2$ in the SI. The CV of the as-deposited film in the basic electrolyte (Figure $2 \mathbf{b}$ ) exhibited the same distinctive features as in the case of CV for the TA-Al(III) mixture with the reduction wave centered at $0.8 \mathrm{~V}$ instead of $0.9 \mathrm{~V}$, revealing the presence of both TA and $\mathrm{Al}(\mathrm{III})$ in the films. This shift could be a result of the lower content of $\mathrm{Al}(\mathrm{III})$ and a different stoichiometry of the $\mathrm{Al}(\mathrm{III}) / \mathrm{TA}$ complexes in the film as compared to in the bulk. The current density registered for the film in the solution was lower in magnitude than the current density registered for $\mathrm{Al}(\mathrm{III})$ in the basic electrolyte by a factor of 10 , prompting the fact that only a small portion of the TA-Al(III) complexes was deposited onto the surface of the QCM sensor from the solutions.

\subsection{Synthesis of Al(III)/(TA@AgNPs) films}

2.2.1. Synthesis of TA@AgNPs. To avoid the use of any additional species, colloidal AgNPs were synthesized in water using TA as both the reducing agent towards $\mathrm{Ag}(\mathrm{I})$ and capping agent 
towards $\mathrm{Ag}(\mathrm{I})$ (Figure 3a) ${ }^{46-48}$ Typically, the use of a single reagent for the synthesis of AgNPs results in particles with a broad range of sizes and geometries with the size of AgNPs obtained via reduction by TA ranging from 7 to $200 \mathrm{~nm}$ and with the highest stability at $2: 1$ TA to $\operatorname{Ag}(\mathrm{I})$ molar ratio. ${ }^{47}$ In order to minimize the size and the polydispersity of AgNPs, the synthesis procedure the overall reagent concentration was increased by 10 -fold and performed at $20 \mathrm{ppm}$ in TA concentration with $\mathrm{TA} / \mathrm{Ag}(\mathrm{I})$ molar ratio of $2: 1$. Due to the increase in the overall concentration of both the reduced species, $\mathrm{Ag}(\mathrm{I})$, and the reducing and stabilizing agent, TA, the decrease in the diameter of the nanoparticle was observed due to the steric limitation, but for the cost of their stability in time. ${ }^{47}$ The hydrodynamic size and stability of the TA@ AgNPs was assessed by DLS (Figure 3b).

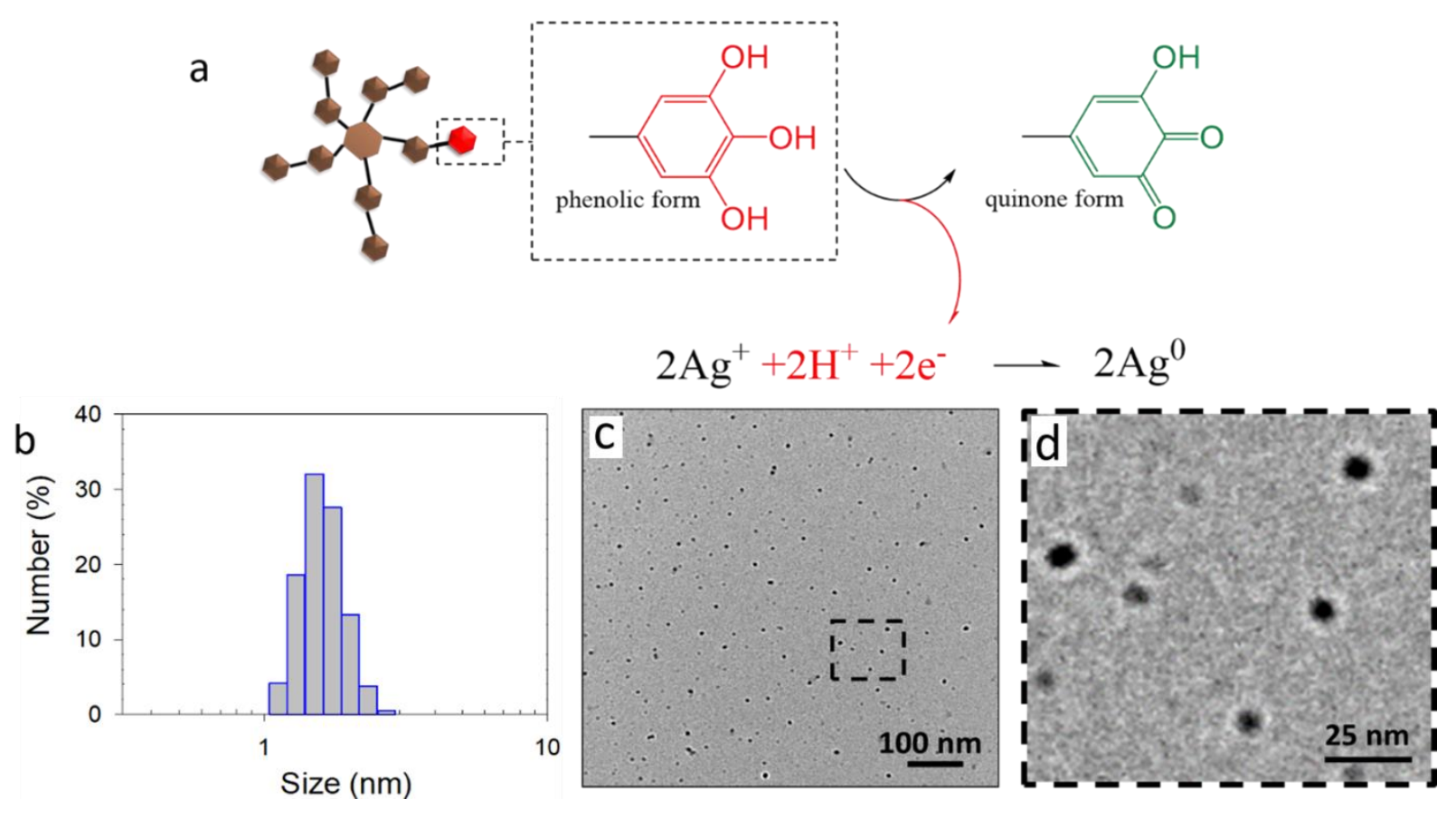

Figure 3. TA@AgNPs characterization (a) mechanism of TA@AgNPs formation via direct reduction of $\mathrm{Ag}(\mathrm{I})$ ions by TA in water, (b) size distribution, determined by DLS, after synthesis and (c) the corresponding TEM image in a dry state with (d) zoom-in of the dashed box. 
Directly after the synthesis, the size of the NPs ranged from 1 to $4 \mathrm{~nm}$ with a maximum at $2 \mathrm{~nm}$ and promptly increasing in time due to the proceeding aggregation of the nanoparticles. At the ED time (3 min after their synthesis), the lower-sized species have not been observed and the maximum in the histogram was shifted to $3 \mathrm{~nm}$, with the sizes ranging between 2 and $4 \mathrm{~nm}$ (Figure S3 in the SI). The TEM images revealed regular and uniformly distributed metal species of up to $10 \mathrm{~nm}$ in diameter (Figure 3c and $\mathbf{d}$ ). The size of TA@AgNPs in TEM images is $6 \pm 2 \mathrm{~nm}$ by Image $J$ treatment. The size obtained by DLS is between 2 and $4 \mathrm{~nm}$. The sizes are similar which could be explained by the small thickness of TA adsorbed on the surface of the AgNPs.

2.2.2. Formation of Al(III)/(TA@AgNPs) complexes. Figure 4a shows the procedure adapted for the electrochemically triggered self-assembly of the $\mathrm{Al}(\mathrm{III})$-imprinted film based on AgNPs and TA. TA@AgNPs obtained via the procedure described in the previous section were subjected to complexation by $\mathrm{Al}(\mathrm{III})$ at $\mathrm{Al}(\mathrm{III}) / \mathrm{TA}$ molar ratio of 2.5 in $\mathrm{KPF}_{6}$ to form Al(III)/TA@AgNPs. As a result, a mixture of differently sized TA@AgNPs species complexed by $\mathrm{Al}(\mathrm{III})$ via $\mathrm{TA}-\mathrm{Al}(\mathrm{III})^{49}, 50$ coordination bonds at a various ratio has been obtained. By comparing the strength and the character of TA-AgNPs interaction, as well as the TA-Al(III) complex strength, the addition of $\mathrm{Al}(\mathrm{III})$ would cause rather the aggregation of the TA@ $\mathrm{AgNPs}$ species rather than destabilization of the whole mixture and aggregation of AgNPs into bulk silver ${ }^{45}$, similarly as observed for TA-stabilized gold nanoparticles. ${ }^{23}$ The hydrodynamic diameters of $\mathrm{Al}(\mathrm{III}) / \mathrm{TA} @ \mathrm{AgNPs}$ measured by DLS ranged between 2 and $5 \mathrm{~nm}$, with respect to their number with the maximum centered at $3 \mathrm{~nm}$ (Figure 4b). As compared to the size distribution versus intensity of the absorbed light, a negligible number of higher-sized particles was observed as well (Figure S4 in the SI). While the size distribution shifted slightly towards higher diameters comparing to TA@AgNPs (Figure 3a), the overall range has not changed at the ED time, revealing an increased stability in time. In the corresponding TEM images, patch- 
like aggregates upon addition of $\mathrm{Al}(\mathrm{III})$ (Figure $4 \mathbf{c}$ and d) were observed. This observation is in agreement with recent work, reporting the agglomeration of AgNPs in the presence of $\mathrm{Al}(\mathrm{III})$ ions followed by an aggregation-induced fluorescence emission. ${ }^{51}$

a

Electro-cross-linking of Al(III)/(TA@AgNPs)

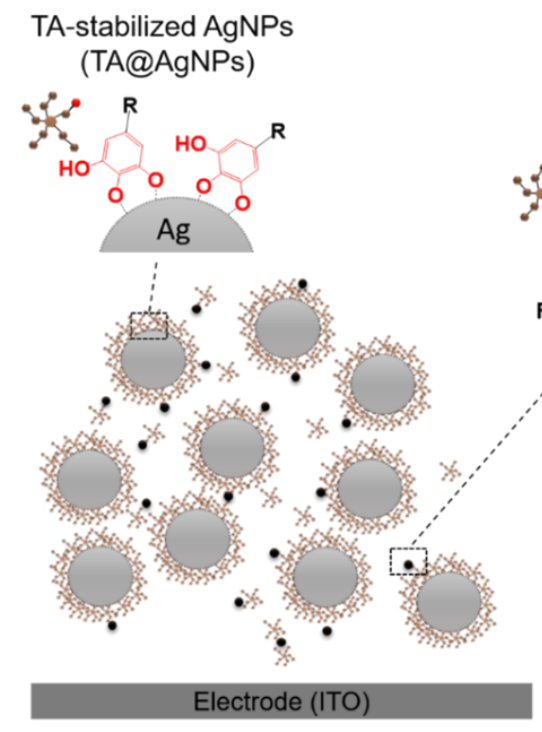

$\mathrm{TA}^{-\mathrm{Al}^{3+}}{ }^{3}$ complex formation Al(III)/(TA@AgNPs)

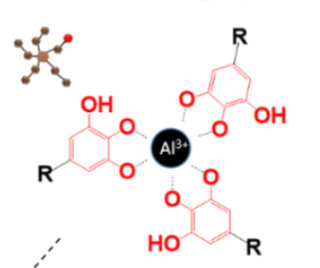

anodic potential $0.7 \mathrm{~V}$

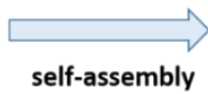

TA polymerization (electro-cross-linking)

self-assembly
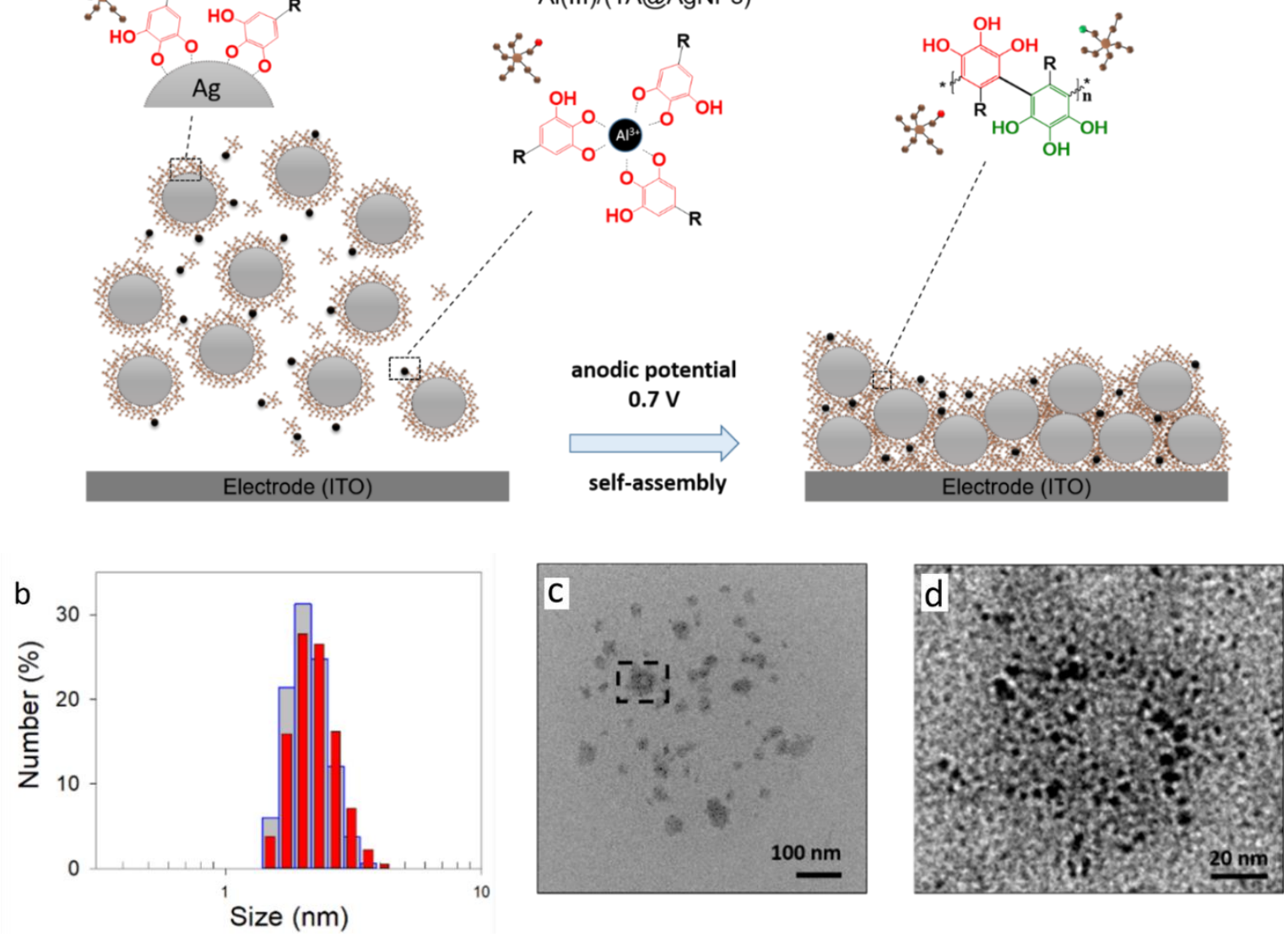

Figure 4 (a) Schematic presentation of the electro-cross-linking of Al(III)/TA@AgNPs suspension, obtained by application of an anodic potential value to form the film on ITO. The ion-printing procedure achieved via incorporation of $\mathrm{Al}(\mathrm{III})$ through coordination bonds with TA and inducing the oxidation of gallol moieties of TA into quinone followed by TA crosslinking. (b) Size distribution of Al(III)/TA@AgNPs obtained by DLS for Al(III)/TA molar ratio of 2.5 , determined by DLS in $0.15 \mathrm{M} \mathrm{KPF}_{6}, 1 \mathrm{~min}$ (blue) and $3 \mathrm{~min}$ (red) after complexation 
with Al(III) and (c) The corresponding TEM image after 1 min of complexation with (d) zoomin of the dashed box.

2.2.3 Electrodeposition of Al(III)/(TA@AgNPs) sensor films. The CV registered for ITO electrode in the Al(III)/(TA@AgNPs) solution at the ED concentration level is shown in Figure 5a.
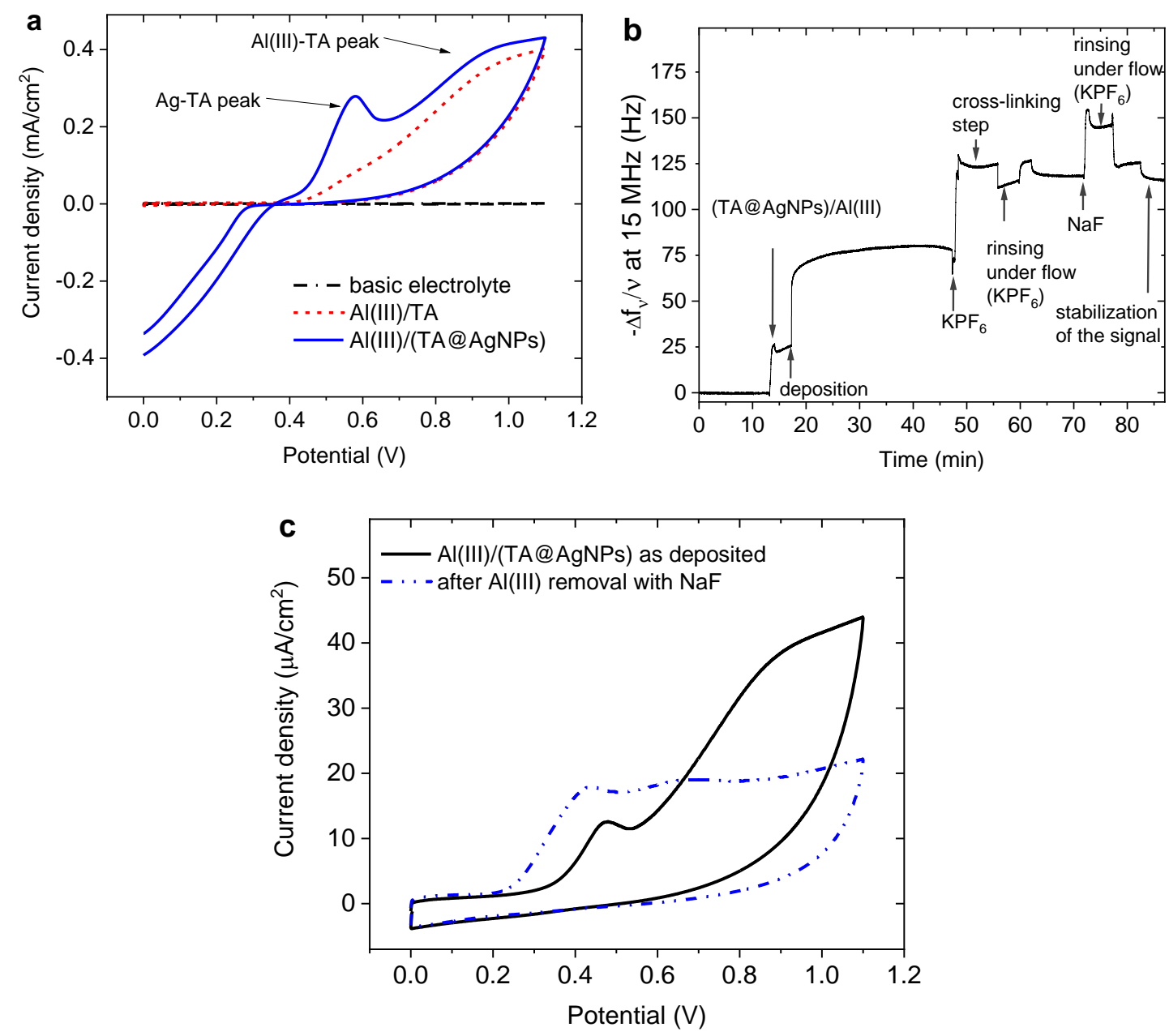

Figure 5 (a) Cyclic voltammograms registered for bare ITO electrode in $0.15 \mathrm{M} \mathrm{KPF}_{6}$ at $\mathrm{pH}$ 7.4 (black dash-dotted line) and solutions containing Al(III)/TA@ AgNPs (solid blue line) and $\mathrm{Al}(\mathrm{III}) / \mathrm{TA}$ (red dash line). (b) Normalized frequency shift, measured by QCM, as a function of time during the electrodeposition of $\mathrm{Al}(\mathrm{III}) / \mathrm{TA} @ \mathrm{AgNPs}$ (2.5 Al(III) to TA molar ratio) in 0.15 M KPF6 at pH 7.4, obtained by application of $0.7 \mathrm{~V}$ for $30 \mathrm{~min}$, followed by a cross-linking step via application of $\mathrm{CV}$ ( 0 to $1.1 \mathrm{~V}$ at $50 \mathrm{mV} / \mathrm{s}$ scan rate) and rinsing steps using $0.15 \mathrm{M}$ 
$\mathrm{KPF} 6$ at $\mathrm{pH}$ 7.4. (c) Cyclic voltammogram, performed at $50 \mathrm{mV} / \mathrm{s}$ in $0.15 \mathrm{M} \mathrm{KPF} 6$ at $\mathrm{pH} 7.4$, of Al(III)/TA@AgNPs coating before (blue dashed line) and after (solid black line) contact with $0.48 \mathrm{M} \mathrm{NaF}$ solution for $5 \mathrm{~min}$. (color online)

In comparison to the $\mathrm{CV}$ curve registered without AgNPs (Fig 2a, solid line), an additional peak centered at ca. $0.55 \mathrm{~V}$ corresponding to TA-AgNPs interaction can be observed (Figure 2c and Figure S5 in the SI). Similarly, as in the case of CV registered for the Al(III)/TA mixture, a signal ascribed to the $\mathrm{Al}(\mathrm{III}) / \mathrm{TA}$ complex oxidation appeared in the solution containing all three species confirming their presence. The ED potential value was set at $0.7 \mathrm{~V}$ in order to ensure the efficient intermolecular cross-linking of TA and their bonding to AgNPs during the film buildup and to be below the oxidation of $\mathrm{Al}(\mathrm{III}) / \mathrm{TA}$ complexes (Figure 5a, dashed line). After injection of $\mathrm{Al}(\mathrm{III}) / \mathrm{TA} @ \mathrm{AgNPs}$ suspension into the QCM cell, an increase in the normalized frequency shift was observed due to non-specific adsorption (Figure 5b). In order to achieve cross-linking of TA and the ED of the film, the applied potential was set to 0.7 $\mathrm{V} .{ }^{52}$ When the electric potential at $0.7 \mathrm{~V}$ was applied, the normalized frequency shift increased rapidly reaching a plateau at $80 \mathrm{~Hz}$. Simultaneously, a steady decrease in the electrical current was observed, exhibiting the characteristics of a typical diffusion-controlled process, with the calculated overall charge density of ca. $0.6 \mathrm{mC} / \mathrm{cm}^{2}$ (Figure S6 in the SI). Coatings based on TA typically exhibit low electrical conductivity because of the lack of conjugated double bonds in the formed coatings. ${ }^{53}$ The increase in thickness of the electrically insulating TA prevent further deposition as observed previously for catechol based molecules. ${ }^{6,52,53}$ After 30 min of electrodeposition, the rinsing step using $0.15 \mathrm{M} \mathrm{KPF}_{6}$ led to an increase in the frequency shift, which could be ascribed to the swelling of the coating. An additional cross-linking step was performed by the application of CV (20 cycles between 0 and $1.1 \mathrm{~V}$ at $50 \mathrm{mV} / \mathrm{s}$ scan rate) with no influence on the frequency shift but with a decrease in the peak current of TA oxidation 
(Figure S7 in the SI). This means that sterically feasible cross-linking of TA occurred in the immobilized Al(III)/TA@AgNPs film.

The $\mathrm{CV}$ registered for $\mathrm{Al}(\mathrm{III}) / \mathrm{TA} @ \mathrm{AgNPs}$ film in $0.15 \mathrm{M} \mathrm{KPF}_{6}$ (Figure 5c) exhibited a signal similar to TA-Al(III) complexes (Figure 2a), i.e. a large peak at $0.9 \mathrm{~V}$, with an additional peak centered at ca. 0.6 V corresponding to TA@AgNPs (Figure 6). The deposition of a nonconductive layer of TA was expected to decrease the electroactive surface area of the electrode. In order to calculate the electroactive surface area and the coatings' capacity as a potential electrochemical sensor Randles-Sevcik equation ${ }^{54}$ was used basing on the position of the $\mathrm{Fe}^{2+} / \mathrm{Fe}^{3+}$ redox pair in the ferro/ferricyanide solution (Figure S8 in the SI). The calculated electrochemical active surface was $0.66 \mathrm{~cm}^{2}$ as compared to the geometric surface of $0.8 \mathrm{~cm}^{2}$, meaning a decrease of ca. $17.5 \%$. The incorporation of conductive AgNPs into the coating as well as metal ions allowed to lower this decrease.

2.2.4. Chemical removal of $\mathrm{Al}(\mathrm{III})$ ions from $\mathrm{Al}(\mathrm{III}) / \mathrm{TA} @ \mathbf{A g N P s}$ films. After the ED of Al(III)/TA@AgNPs coating, Al(III) ions were removed by soaking in $0.48 \mathrm{M} \mathrm{NaF}$ solution, prepared in $0.15 \mathrm{M} \mathrm{KPF}_{6}$. The principle of the removal was based on the formation of watersoluble Al-F complexes ${ }^{55-57}$ with stability constants $\left(\beta_{\mathrm{n}}\right)$ ranging from 7 to $19.8^{58,59}$ which are significantly higher than for the $\mathrm{Al}(\mathrm{III})-\mathrm{TA}$ complexes $\left(\beta_{\mathrm{n}}=5.25^{60}\right)$. The injection of $\mathrm{NaF}$ solution resulted in an increase in the normalized frequency shift, probably due to the change of solvent bulk properties (viscosity and density) (Figure S9 in the SI). After the rinsing step using $0.15 \mathrm{M} \mathrm{KPF}_{6}$ solution under a flow rate of $600 \mu \mathrm{L} / \mathrm{min}$, the stabilization of the signal was obtained at rest with no variation in the frequency value in comparison to before the contact with $\mathrm{NaF}$. After the removal of $\mathrm{Al}(\mathrm{III})$ ions, the $\mathrm{CV}$ registered showed two typical irreversible oxidation peaks of TA bonded to a metal species at ca. 0.4 and $0.6 \mathrm{~V}$ corresponding to the AgNPs-TA bonds (Figure 5c). The signal ascribed previously to TA/Al(III) at ca. $0.9 \mathrm{~V}$ 
disappeared which demonstrated that the removal of the $\mathrm{Al}(\mathrm{III})$ ions was successful and the film was robust upon removal of $\mathrm{Al}(\mathrm{III})$.

\subsubsection{Characterization of Al(III)/TA@AgNPs coatings. The morphology of} Al(III)/TA@AgNPs coatings was characterized by SEM (Figure 6). The surface of the coating exhibited irregularly distributed aggregates of comparable size. The phenomenon of strong backscattering of electrons (BSE) on heavy elements was used to follow the distribution of $\mathrm{Ag}$ over the surface area of Al(III)/TA@AgNPs coatings. Heavier elements appear brighter due to the higher intensity of the secondary electrons backscattered from the surface. The aggregates appeared significantly brighter than the rest of the surface when imaged in the LA-BSE mode which indicates the relatively high in $\mathrm{Ag}$ in the aggregates, as compared to the films deposited without the addition of AgNPs (Figure S10 in the SI).
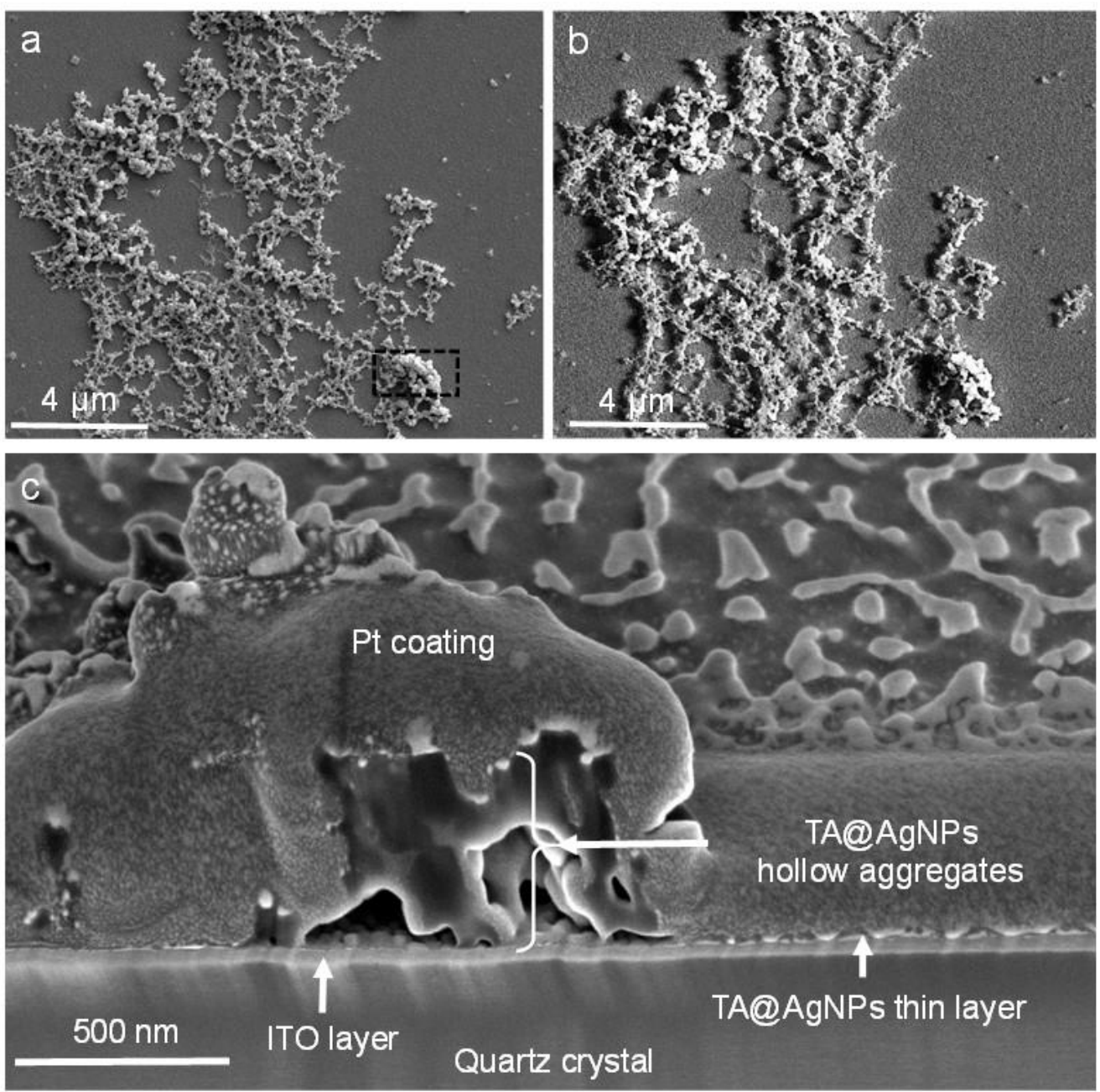
Figure 6. SEM images of Al(III)/TA@AgNPs coatings (a, b) top views obtained in SE (a) and BSE (b) modes and (c) cross-section of the dashed rectangle area of image (a) observed by FIB in SE mode after the deposition of the $200 \mathrm{~nm}$ Pt stripe.

The cross-sectional cut, performed with the focused ion beam (FIB) after the deposition of 200 $\mathrm{nm}$ platinum $(\mathrm{Pt})$ layer onto the sample, revealed that the aggregates were partially hollow structures of ca. $500 \mathrm{~nm}$ in height (Figure 6c). The granular surface under the hollow coatings was attributed to the ITO layer grains of up to $50 \mathrm{~nm}$ in height. On the rest of the electrode surface, a bright planar and thin coating was observed corresponding to a thin deposition of Al(III)/TA@AgNPs.

XPS investigation allowed the determination of both atomic and chemical composition of the coatings. In the XPS survey spectrum of Al(III)/TA@AgNPs coating carbon $(\mathrm{C})$, oxygen $(\mathrm{O})$, silver (Ag) and aluminum were detected (Figure S11 in the SI). The C1s peak at $285 \mathrm{eV}$ (used as an internal calibration peak) and $\mathrm{O} 1 \mathrm{~s}$ at peak $534 \mathrm{eV}$ represented 50 and 48 at.\%, respectively, confirming the presence of TA, the only carbon-containing compound present in the starting solution (Figure 7).

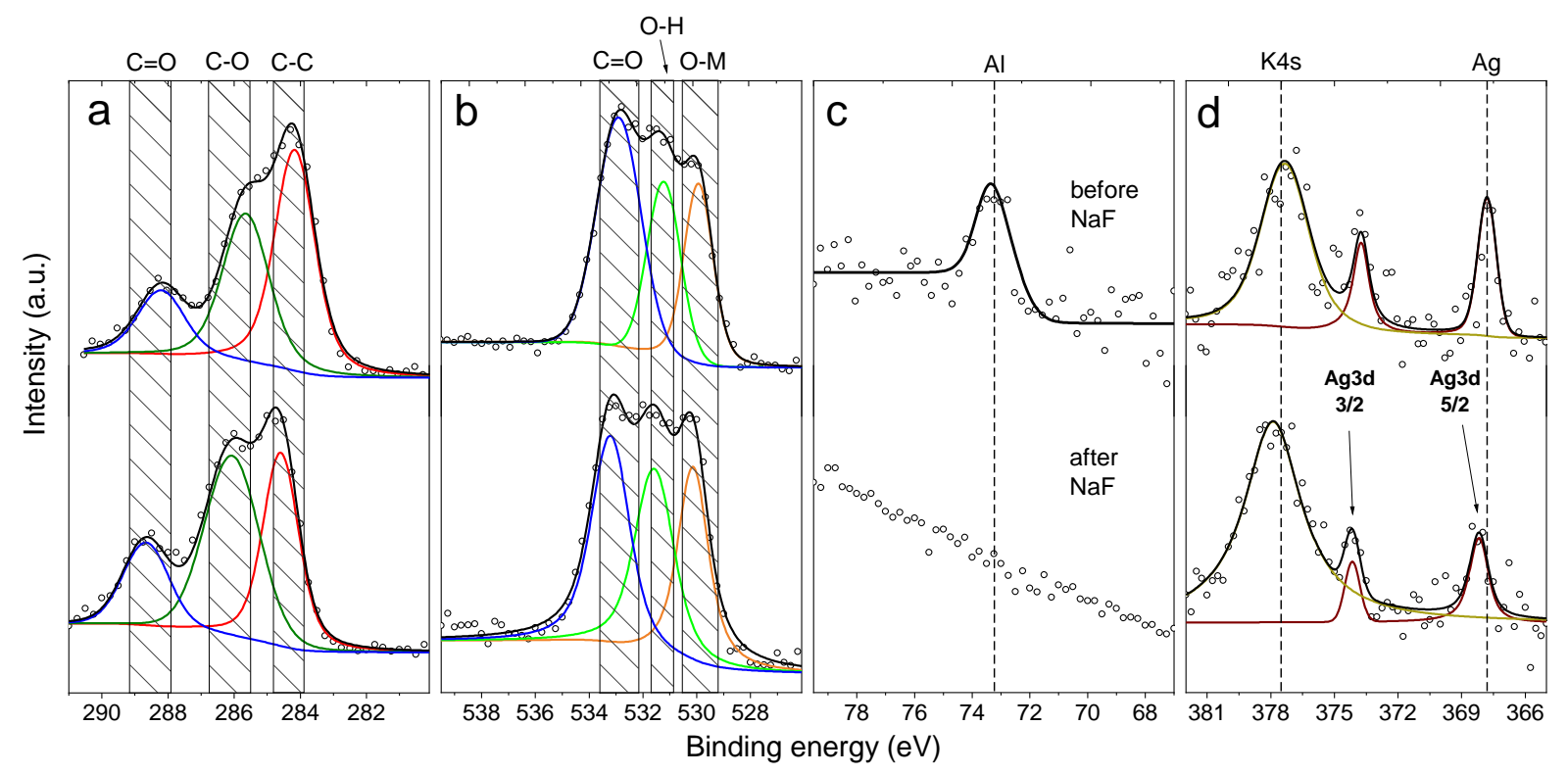


Figure 7. XPS (a) C1s, (b) O1s, (c) Al2p and (d) Ag3d core level spectra of Al(III)/TA@ AgNPs coating obtained after 30 min deposition time before and after treatment with $0.48 \mathrm{M} \mathrm{NaF}$ solution.

The doublet in the $\mathrm{Ag} 3 \mathrm{~d}$ spectrum with the $\mathrm{Ag} 3 \mathrm{~d}_{5 / 2}$ signal centered at ca. $368 \mathrm{eV}$ corresponds to the metallic form of silver, ${ }^{61}$ confirming the presence of AgNPs with an estimated atomic concentration of 0.9 at.\%. In this region, a signal corresponding to $\mathrm{K} 4 \mathrm{~s}$ was deconvoluted as well, prompting that some content of the basic electrolyte persisted in the coatings after rinsing them with water. A12p spectrum revealed a single signal at ca. $73 \mathrm{eV}$ corresponding to metallic $\mathrm{Al},{ }^{61}$ confirming the coordination character of the TA-Al bond with an atomic concentration of $\mathrm{Al}$ at 1.3 at. $\%$.

After the chemical removal of $\mathrm{Al}(\mathrm{III})$, the Al2p signal in the XPS spectrum disappeared after the treatment with the fluoride solution, confirming the complete removal of $\mathrm{Al}(\mathrm{III})$ ions from the coating (Figure 5c and Figure 7). On the other hand, the intensity of the C1s component signal corresponding to carbon single-bonded to oxygen increased, confirming the release of $\mathrm{Al}(\mathrm{III})$ ions from a complex formed with the phenol groups. The atomic concentration of $\mathrm{Ag}$ remained at the same level before and after the removal of $\mathrm{Al}(\mathrm{III})$ ions.

\subsection{Al(III) sensing properties of TA@AgNPs coatings in physiological conditions. After} the complete removal of $\mathrm{Al}(\mathrm{III})$, the rebinding of $\mathrm{Al}(\mathrm{III})$ by $\mathrm{TA} @ \mathrm{AgNPs}$ coatings was first studied in HEPES-buffered $0.15 \mathrm{M} \mathrm{NaCl}$ solution at $\mathrm{pH} 7.4$ (HEPES). Figure S12 in the SI shows a typical cyclic voltammogram of TA@AgNPs coating registered in HEPES buffer. In contrast to the $\mathrm{CV}$ obtained in $\mathrm{KPF}_{6}$ solution (Figure 5c), a sharp oxidation peak at ca. $0.12 \mathrm{~V}$ characteristic for AgNPs appeared because of the presence of $\mathrm{NaCl}^{62,63}$ To move forward to a physiological medium, $10 \%$ of human serum (HS) was added to the HEPES buffer (labeled as HS-HEPES buffer). 
While TA forms complexes with $\mathrm{Al}(\mathrm{III})$ that can be probed electrochemically, ${ }^{64}$ it can also interact with proteins present in the human serum ${ }^{65}$ and thus could interfere with the sensing of Al(III). To avoid this interference before each measurement, TA@AgNPs coatings in contact HS-HEPES buffer underwent the application of CV cycles until the stabilization of the CV signal (Figure S10 in the SI). After this step, TA@AgNPs coating was put in contact for 5 min with $\mathrm{Al}(\mathrm{III})$ solutions, prepared at different concentrations in HS-HEPES buffer. To perform $\mathrm{Al}(\mathrm{III})$ sensing, a $\mathrm{CV}$ was performed between 0 and $1 \mathrm{~V}$ at $5 \mathrm{mV} / \mathrm{s}$ scan rate (Figure 8a).

a

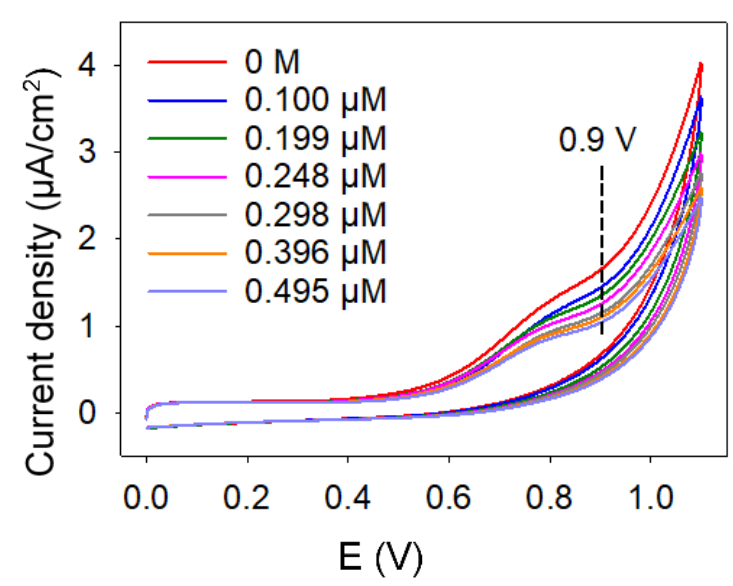

b

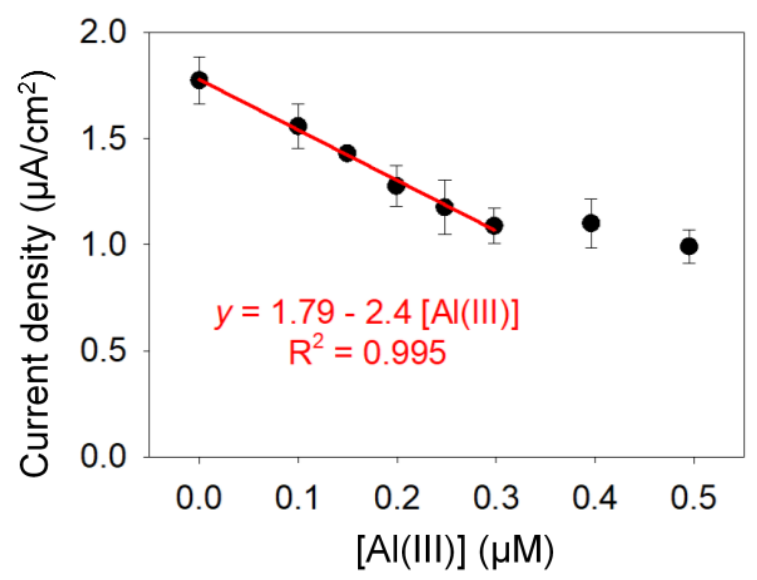

Figure 8. a) Cyclic voltammogram of TA@AgNPs coatings, registered at $5 \mathrm{mV} / \mathrm{s}$ in $\mathrm{HS}$ HEPES buffer, in the presence of different concentrations of $\mathrm{Al}$ (III) ranging from 0 to 0.495 $\mu \mathrm{M}$. (b) Evolution of the current density, measured at $0.9 \mathrm{~V}$ in the $\mathrm{CV}$, as a function of $\mathrm{Al}(\mathrm{III})$ concentration. The data represents the mean and standard deviation of three independent experiments. The point without an error bar presents an additional measurement of one of the independent experiment.

Only one oxidation signal can be distinguished spreading from ca. 0.5 to ca. $1 \mathrm{~V}$, preceded by a current plateau and followed by a steep increase in the current magnitude corresponding to the continuous oxidation of the coating. After each sensing, TA@AgNPs coating was regenerated by $\mathrm{NaF}$ treatment and HS-HEPES soaking to be reused for the following $\mathrm{Al}(\mathrm{III})$ concentration. Following, after the rinsing step with HEPES buffer followed by removal of 
Al(III) ions using NaF solution, another rinsing step with HEPES buffer and then with HSHEPES. A decrease in the current density value of the oxidation wave was observed with the increase in $\mathrm{Al}(\mathrm{III})$ concentration. The difference in the current magnitude registered for a different level of $\mathrm{Al}(\mathrm{III})$ was the most visible at $0.9 \mathrm{~V}$ (Figure 8a, dashed line). The value of the current density measured at $0.9 \mathrm{~V}$ was then plotted as a function of $\mathrm{Al}(\mathrm{III})$ concentration to obtain a calibration curve. Figure $\mathbf{8 b}$ shows the evolution of the current density, mean and standard deviation of three independent experiments as a function of $\mathrm{Al}(\mathrm{III})$ concentration.

The curve showed a linear dependency $\left(\mathrm{R}^{2}=0.995\right)$ in the concentration range of 0.10 to 0.298 $\mu \mathrm{M}$ in $\mathrm{Al}(\mathrm{III})$, which deviates from linearity at a higher concentration. The observed sensitivity, calculated from the slope of the calibration curve, was $-2.4 \mu \mathrm{A} / \mathrm{mM} \mathrm{cm}{ }^{2}$ with a detection capacity at $0.13 \mu \mathrm{M}$ (limit of detection, at a signal-to-noise ratio of 3). ${ }^{66}$ According to the literature, the toxic level of $\mathrm{Al}(\mathrm{III})$ in plasma (i.e. serum) is above $2.3 \mu \mathrm{M}$ for children and 7.4 $\mu \mathrm{M}$ for adults. ${ }^{67}$ As the calibration curve was obtained in diluted human serum at $10 \%$, TA@AgNPs coatings could be used on 10-fold diluted plasma samples of children to discriminate between $\mathrm{Al}(\mathrm{III})$ normal and toxic level, with a detection limit of $1.3 \mu \mathrm{M}$ and a linear range up to $2.98 \mu \mathrm{M}$ in the plasma.

CONCLUSIONS: A novel ionically-imprinted thin sensor film based on tannic acid and silver nanoparticles, tailor-designed for voltammetric tracing of aluminum ions in biological fluids was obtained via electrochemically assisted self-assembly onto ITO electrode. The modified colloidal synthesis of AgNPs via direct reduction by TA resulted in the fabrication of TAstabilized nanoparticles of a significantly decreased size of a few nanometers, as compared to the literature. The XPS analysis revealed that the fabricated Al(III)/(TA@AgNPs) film contained ca. 2 at.\% of Al, which could be completely removed from the layer by soaking in a fluoride solution, basing on the strong complexation of $\mathrm{Al}(\mathrm{III})$ by fluoride ions. The determined $\mathrm{Ag}$ content was ca. 1 at.\% which persisted after the removal of $\mathrm{Al}(\mathrm{III})$ ions and the 
corresponding $\mathrm{BE}$ value was assigned to $\mathrm{Ag}$ in the metallic form, proving the successful incorporation of AgNPs in situ during the self-assembly of the film. By chemical removal of Al(III) using NaF solution, ion-imprinted TA@AgNPs coating was obtained. A correlation between the current density value measured at $0.9 \mathrm{~V}$ and the concentration of $\mathrm{Al}(\mathrm{III})$ was established between 0.10 and $0.298 \mu \mathrm{M}(2.7-8.05 \mu \mathrm{g} / \mathrm{L})$ with a LOD value of $0.13 \mu \mathrm{M}$. These results show the high applicability of the electrochemically assisted self-assembly to produce complex supramolecular thin sensor films tailor-designed for the targeted metal ion sensing. This could contribute to the development of electrochemical sensors for the monitoring of $\mathrm{Al}(\mathrm{III})$ in 10-fold diluted plasma in particular for long-term dialysis patients.

\section{Material and methods}

3.1 Materials. Tannic acid (TA, A.C.S. reagent grade), potassium hexafluorophosphate $\left(\mathrm{KPF}_{6}\right.$, $\geq 99 \%$ ) and human serum (from human male AB plasma, USA origin, sterile-filtered) were purchased from Sigma-Aldrich. Aluminum nitrite $\left(\mathrm{Al}\left(\mathrm{NO}_{3}\right)_{3} \cdot 9 \mathrm{H}_{2} \mathrm{O}, 98 \%\right)$, silver nitrite $\left(\mathrm{AgNO}_{3}, 99+\%\right)$ and sodium fluoride $(\mathrm{NaF}, 99 \%)$ were purchased from Alfa Aesar. Potassium hexacyanoferrate (III) $\left(\mathrm{K}_{4} \mathrm{Fe}(\mathrm{CN})_{6}\right)$ was acquired from Merck. 4-(2-hydroxyethyl)-1piperazineethanesulfonic acid (HEPES, for molecular biology, $\geq 99 \%$ ), sodium chloride ( $\mathrm{NaCl}$, anal. reag. grade $\geq 99.5 \%$ ) and potassium chloride $(\mathrm{KCl})$ grade were purchased from Fischer Scientific. All chemicals were used as received. All solutions were prepared using doubly distilled MilliQ water. All solutions used for electrodeposition were prepared in $0.15 \mathrm{M} \mathrm{KPF}_{6}$ aqueous solutions adjusted at $\mathrm{pH} 7.4$ with aqueous $\mathrm{KOH}$ solutions unless otherwise stated.

\subsection{Electrochemical Quartz Crystal Microbalance (QCM) with Dissipation Monitoring.}

QCM experiments were performed using a Q-Sense E1 apparatus from Q-Sense AB (Gothenburg, Sweden) by monitoring the changes in the resonance frequency $f_{v}$ and the dissipation factor $D_{v}$ of an oscillating quartz crystal upon adsorption of a viscoelastic layer ( $v$ 
represents the overtone number, equal to $1,3,5,7)$. The quartz crystal was excited at its fundamental frequency $(5 \mathrm{MHz})$, and the measurements were performed at the first, third, fifth, and seventh overtones, corresponding to 5, 15, 25, and $35 \mathrm{MHz}$, respectively. In each case, only the third overtone at $15 \mathrm{MHz}$ is presented. QCM measurement is sensitive to the amount of water associated with the adsorbed molecules and senses the viscoelastic changes in the electrode/electrolyte interface. The indium tin oxide coated QCM (ITO-QCM, MicroVacuum Ltd., Budapest, Hungary) sensor acted as the working electrode. A platinum electrode (counter electrode) on the top of the electrochemical QCM cell and a no-leak $\mathrm{Ag} / \mathrm{AgCl}$ reference electrode (Dri-Ref ${ }^{\mathrm{TM}}$, World Precision Instruments, $3 \mathrm{M} \mathrm{KCl}$ ) fixed in the outlet flow channel were used as counter and reference electrodes, respectively. All potential values are given with respect to the $\mathrm{Ag} / \mathrm{AgCl}$ reference electrode. Electrochemical measurements were performed using CHI660E apparatus from $\mathrm{CH}$ Instrument (Austin, Texas) coupled on the QCM-D apparatus. Before the buildup of the coating, the ITO-QCM crystal was cleaned by UV-ozone treatment for $15 \mathrm{~min}$. The $\mathrm{Ag} / \mathrm{AgCl}$ reference electrode was frequently tested by cyclic voltammetry $(\mathrm{CV})$ in $\mathrm{K}_{4} \mathrm{Fe}(\mathrm{CN})_{6}$ aqueous solution to ensure the potential stability and correctness. $\mathrm{K}_{4} \mathrm{Fe}(\mathrm{CN})_{6}$ prepared in $0.15 \mathrm{M} \mathrm{KPF}_{6}$ solution ( $\mathrm{pH} 3.7$ ) was routinely injected into the electrochemical QCM cell with the ITO crystal as the working electrode to monitor its cyclic voltammogram taken as reference. The presence of the two peaks and the potential values of redox reactions of the $\mathrm{Fe}(\mathrm{II}) / \mathrm{Fe}(\mathrm{III})$ redox pair were verified. A surface area of $0.8 \mathrm{~cm}^{2}$, corresponding to the exposed area of the ITO QCM sensor, was used for all current density calculations.

3.3 Silver nanoparticles synthesis. TA@ AgNPs were obtained via direct reduction of $\mathrm{AgNO}_{3}$ $(1 \mathrm{mg} / \mathrm{mL})$ dissolved in MilliQ water at $0.5 \mathrm{mg} / \mathrm{mL}$ by TA $(10 \mathrm{mg} / \mathrm{mL})$ corresponding to $\mathrm{Ag}(\mathrm{I}) / \mathrm{TA}$ molar ratio of 0.5 . Following, the mixture was sonicated for $5 \mathrm{~min}$ at room 
temperature to allow enough time for the $\mathrm{Ag}(\mathrm{I})$ reduction reaction and TA adsorption on the surface of the newly formed AgNPs while slowing down their aggregation rate.

3.4 Buildup Procedure of Al(III)/TA coating. The complexes of TA with Al(III) were obtained by mixing the TA solution with the same volume of $29 \mu \mathrm{M} \mathrm{Al}(\mathrm{III})$ solution, both prepared in $0.15 \mathrm{M} \mathrm{KPF}_{6}$, resulting in a mixture at $\mathrm{Al}(\mathrm{III}) / \mathrm{TA}$ molar ratio of 2.5. To ensure enough ionic conductivity of the building solutions, all the experiments of electrodeposition were performed in the presence of $0.15 \mathrm{M} \mathrm{KPF}_{6}$. After the stabilization of the QCM signal in contact with $0.15 \mathrm{M} \mathrm{KPF}_{6}$ solution, $\mathrm{Al}(\mathrm{III}) / \mathrm{TA} @ \mathrm{AgNPs}$ suspension was injected into the electrochemical cell $(600 \mu \mathrm{L})$ at a flow rate of $400 \mu \mathrm{L} / \mathrm{min}$ with a peristaltic pump. After the stabilization of the signal, a constant potential of $0.7 \mathrm{~V}$ was applied for 30 min to trigger the crosslinking between TA molecules and start the electrodeposition of the coating. After the deposition, an aqueous solution of $0.15 \mathrm{M} \mathrm{KPF}_{6}(600 \mu \mathrm{L})$ was injected to rinse the coating. Then, the application of $\mathrm{CV}$ (20 cycles, $0-1.1 \mathrm{~V}$ at $50 \mathrm{mV} / \mathrm{s}$ in scan rate) was performed to obtain an additional cross-linking between the TA molecules of the coating to improve its mechanical stability.

3.5 Buildup Procedure of Al(III)/TA@AgNPs coating. The complexation of TA@AgNPs with $\mathrm{Al}(\mathrm{III})$ was performed by mixing the synthesized TA@AgNPs suspension with the same volume of $29 \mu \mathrm{M} \mathrm{Al(III)} \mathrm{solution} \mathrm{in} 0.3 \mathrm{M} \mathrm{KPF}_{6}$ to obtain a final electrodeposition (ED) mixture at $\mathrm{Al}(\mathrm{III}) / \mathrm{TA}$ molar ratio of 2.5 in $0.15 \mathrm{M} \mathrm{KPF}_{6}$. Next, the same procedure as in part 3.4 was followed for the injection and deposition of the coating. After the cross-linking step, a 0.48 $\mathrm{M} \mathrm{NaF}$ solution, prepared in $0.15 \mathrm{M} \mathrm{KPF}_{6}$ solution, was injected in order to remove $\mathrm{Al}(\mathrm{III})$ ions from the coating and thus, create "holes" ready to bind the $\mathrm{Al}(\mathrm{III})$. After the stabilization of the QCM signal, the coating was rinsed by $0.15 \mathrm{M} \mathrm{KPF}_{6}$ for 2 min under flow. To ensure the complete removal of the $\mathrm{Al}(\mathrm{III})$ ions, $\mathrm{CV}$ monitoring after each injection of $\mathrm{NaF}$ solution was performed. Prior to further microscopic and spectroscopic characterization, MilliQ water was 
injected into the cell after the buildup to rinse the coating and avoid any additional signals were present in the spectra of the coatings.

3.6 Electroactive surface area of the coatings. In order to calculate the electroactive surface area and the coatings' capacity as a potential electrochemical sensor Randles-Sevcik equation ${ }^{54}$ was utilized (Equation 1) basing on the position of the $\mathrm{Fe}^{2+} / \mathrm{Fe}^{3+}$ redox pair in the ferro/ferricyanide solution (Figure S7 in the SI).

$$
I_{p}=0.4463 \times\left(\frac{F^{3}}{R T}\right)^{1 / 2} \times n^{3 / 2} \times A_{e f f} \times D^{1 / 2} \times C \times v^{1 / 2}
$$

where $I_{p}$ is the peak current, $F$ is the Faraday constant $(96485.3 \mathrm{C} / \mathrm{mol}), R$ is the universal gas constant $(8.31 \mathrm{~J} / \mathrm{Kmol}), T$ is the temperature $(293.15 \mathrm{~K}), n$ the number of moles of electrons transferred in the reaction (for ferrocyanide/ferricyanide $n=1$ ), $A_{e f f}$ is the active surface of the electrode $\left(\mathrm{cm}^{2}\right), D$ the diffusion coefficient of electroactive species $\left(0.72 \times 10^{-5}\right.$ and $0.67 \times$ $10^{-5} \mathrm{~cm}^{2} / \mathrm{s}^{1}$ for ferricyanide and ferrocyanide, respectively) ${ }^{68}, C$ is the concentration of electroactive species $(1.18 \mathrm{mM})$ and $v$ is the potential sweep rate $(50 \mathrm{mV} / \mathrm{s})$.

\subsection{Voltammetric sensing of Al(III) in HS using TA@AgNPs coating. Human serum} solution was prepared at $10 \%$ in volume in $10 \mathrm{mM}$ HEPES $0.15 \mathrm{M} \mathrm{NaCl}$ at $\mathrm{pH} 7.4$, referred to as HS-HEPES. The $\mathrm{pH}$ value of HS-HEPES was adjusted at $\mathrm{pH} 7.4$ with aqueous $\mathrm{NaOH}$ solution. After the removal of $\mathrm{Al}(\mathrm{III})$ by $\mathrm{NaF}$ treatment and a rinsing step of TA@AgNPs coating with $0.15 \mathrm{M} \mathrm{KPF}_{6}, 500 \mu \mathrm{l}$ of HS-HEPES solution was injected into the QCM cell before the application of $\mathrm{CV}$ (10 cycles at $50 \mathrm{mV} / \mathrm{s}$ sweep rate) to satiate the coatings with proteins from HS. In the following, Al(III) solution prepared in HS-HEPES was injected in the QCM cell and a CV scan at $5 \mathrm{mV} / \mathrm{s}$ in scan rate was recorded for $\mathrm{Al}(\mathrm{III})$ sensing. After each sensing, TA@AgNPs coating was regenerated by NaF treatment and HS-HEPES soaking to be reused for the following $\mathrm{Al}(\mathrm{III})$ concentration. 
3.8 Spectroscopic characterization of the coatings. X-ray Photoelectron Spectroscopy (XPS) measurements were performed using a VG ESCALAB 210 system equipped with a monochromatized $\mathrm{Al} \mathrm{K \alpha}(\mathrm{h} v=1486.6 \mathrm{eV})$ radiation source with the pass energy of $20 \mathrm{eV}$ used for all narrow scan measurements. The photoemission spectra were recorded at normal emission with an overall resolution of about $0.6 \mathrm{eV}$. The energy positions of the spectra were calibrated with reference to the $4 \mathrm{f}_{7 / 2}$ level of a clean gold sample at $84.0 \mathrm{eV}$ binding energy (BE) value. Fitting of the data was performed using Doniach-Sunjic functions, ${ }^{69}$ after a Shirley background fitting ${ }^{70}$ with the help of UNIFIT 2016 software. ${ }^{71}$ A convolution of Lorentzian and Gaussian line shapes was used to fit the individual peaks. After this, the intensities were estimated by calculating the integral of each peak. The atomic concentrations were then derived using Scofield sensitivity factors ${ }^{72}$. No charging of the surface during the measurement was observed.

3.9 Dynamic light scattering. Size distribution histograms of AgNPs were recorded using dynamic light scattering (DLS) method on Zetasizer Nano ZS (Malvern Instruments Ltd., GB) in $12 \mathrm{~mm}$ disposable polystyrene cuvettes (DTS0012, Brand, Germany). The measurements were performed at an ambient temperature of $25^{\circ} \mathrm{C}$ after $30 \mathrm{~s}$ of equilibration time with 0.135 and 3.990 as the refractive index and adsorption coefficient of AgNPs, respectively. ${ }^{73}$ The viscosity for the dispersant (water) was set to $0.8872 \mathrm{cP}$ and the refractive index to 1.330 .

3.10 Microscopic characterization. Scanning electron microscopy (SEM) images were registered with a Hitachi S-4800 microscope in secondary electron (SE) and back-scattered secondary electron (LA-BSE) mode. To obtain the cross-section of the coating, NanoLab 600 Helios (FEI company) device, which is a combined SEM and focused ion beam (FIB) facility using $30 \mathrm{keV} \mathrm{Ga}$ ions for cutting, was used. A layer of $200 \mathrm{~nm}$ platinum $(\mathrm{Pt})$ was used to protect the sample surface at the cross-section edge. For the transmission electron micrographs, $5 \mu \mathrm{l}$ of the nanoparticles suspension (diluted by a factor of 3) was deposited onto a freshly glow discharged carbon-covered grid (400 mesh). The suspension was left for 2 minutes and then 
dried using a filter paper. The grids were observed at $200 \mathrm{kV}$ with a Technai G2 (FEI) microscope. Images were acquired with an Eagle 2k (FEI) ssCCD camera.

\section{ASSOCIATED CONTENT}

Supporting Information. Normalized frequency shift and ED current registered during the deposition of Al(III)-TA films onto ITO electrode; Cyclic voltammograms of ITO electrode in $\mathrm{KPF}_{6}$ and $\mathrm{Al}(\mathrm{III}) / \mathrm{KPF}_{6}$ solutions; TA@AgNPs size distribution determined by DLS in water directly after the synthesis and at the ED time; Cyclic voltammogram of Al(III)/TA@AgNPs coating electrodeposited at the cross-linking step after electrodeposition; Cyclic voltammograms of $\mathrm{K}_{2} \mathrm{Fe}(\mathrm{CN})_{6}$ before and after the electrodeposition of the $\mathrm{Al}(\mathrm{III}) / \mathrm{TA} @ \mathrm{AgNPs}$ film on ITO-QCM electrode; SEM top-view images of $\mathrm{Al}(\mathrm{III}) / \mathrm{TA}$ coatings deposited onto ITO surface obtained in SE and BSE modes; XPS survey spectra of Al(III)/(TA@AgNPs) film before and after $\mathrm{NaF}$ treatment.

\section{AUTHOR INFORMATION}

\section{Corresponding Author}

*a.krywko@unibas.ch, *fouzia.boulmedais@ics-cnrs.unistra.fr

\section{Present Addresses}

$\dagger$ Department of Chemistry, University of Basel, Mattenstrasse 24a BPR1096, CH-4058 Basel, Switzerland

\section{Author Contributions}

The manuscript was written through contributions of all authors.

\section{ACKNOWLEDGMENT}


The authors acknowledge the platform of characterization of ICS for the use of the Dynamic Light Scattering. AKC acknowledges Initiative of Excellence (Idex) Post doctorants from Unversité de Strasbourg and Région Grand Est « Jeunes Chercheurs » for financial support. The authors acknowledge Swiss Federal Office for Education and Science (grant no. 1315001762). This work of the Interdisciplinary Institute HiFunMat, as part of the ITI 20212028 program of the University of Strasbourg, CNRS and Inserm, was supported by IdEx Unistra (ANR-10-IDEX-0002) and SFRI (STRAT'US project, ANR-20-SFRI-0012) under the framework of the French Investments for the Future Program. M. H. Iqbal and R. Savin are acknowledged for their support in the processing of the TEM data.

\section{REFERENCES}

1. Jiao, T.; Xing, R.; Ma, K.; Zhang, L., Advances in Design and Self-Assembly of Functionalized LB Films and Supramolecular Gels. Adv. Colloid Sci. 2016, 27-55.

2. Steed, J. W.; Gale, P. A., Supramolecular chemistry: from molecules to nanomaterials. Wiley: 2012.

3. Maerten, C.; Lopez, L.; Lupattelli, P.; Rydzek, G.; Pronkin, S.; Schaaf, P.; Jierry, L.; Boulmedais, F., Electrotriggered confined self-assembly of metal-polyphenol nanocoatings using a morphogenic approach. Chem. Mater. 2017, 29 (22), 9668-9679.

4. El-Maiss, J.; Cuccarese, M.; Maerten, C.; Lupattelli, P.; Chiummiento, L.; Funicello, M.; Schaaf, P.; Jierry, L.; Boulmedais, F., Mussel-Inspired Electro-Cross-Linking of Enzymes for the Development of Biosensors. ACS Appl. Mater. Interfaces 2018, 10 (22), 18574-18584. 5. Rydzek, G.; Jierry, L.; Parat, A.; Thomann, J. S.; Voegel, J. C.; Senger, B.; Hemmerlé, J.; Ponche, A.; Frisch, B.; Schaaf, P., Electrochemically Triggered Assembly of Films: A One-Pot Morphogen-Driven Buildup. Angew. Chem., Int. Ed. 2011, 50 (19), 4374-4377. 
6. Maerten, C.; Garnier, T.; Lupattelli, P.; Chau, N. T. T.; Schaaf, P.; Jierry, L.;

Boulmedais, F., Morphogen electrochemically triggered self-construction of polymeric films based on mussel-inspired chemistry. Langmuir 2015, 31 (49), 13385-13393.

7. Rydzek, G.; Garnier, T.; Schaaf, P.; Voegel, J.-C.; Senger, B.; Frisch, B.; Haikel, Y.; Petit, C.; Schlatter, G.; Jierry, L., Self-construction of supramolecular polyrotaxane films by an electrotriggered morphogen-driven process. Langmuir 2013, 29 (34), 10776-10784.

8. $\quad$ Rydzek, G.; Schaaf, P.; Voegel, J.-C.; Jierry, L.; Boulmedais, F., Strategies for covalently reticulated polymer multilayers. Soft Matter 2012, 8 (38), 9738-9755.

9. Rydzek, G.; Toulemon, D.; Garofalo, A.; Leuvrey, C.; Dayen, J. F.; Felder-Flesch, D.; Schaaf, P.; Jierry, L.; Begin-Colin, S.; Pichon, B. P., Selective Nanotrench Filling by One-Pot Electroclick Self-Constructed Nanoparticle Films. Small 2015, 11 (36), 4638-4642.

10. Dochter, A.; Garnier, T.; Pardieu, E.; Chau, N. T. T.; Maerten, C.; Senger, B.; Schaaf, P.; Jierry, L.; Boulmedais, F., Film self-assembly of oppositely charged macromolecules triggered by electrochemistry through a morphogenic approach. Langmuir 2015, 31 (37), 10208-10214.

11. Zhang, X.; Parekh, G.; Guo, B.; Huang, X.; Dong, Y.; Han, W.; Chen, X.; Xiao, G., Polyphenol and self-assembly: metal polyphenol nanonetwork for drug delivery and pharmaceutical applications. Future Drug. Discov. 2019, 1, FDD7

12. Rahim, M. A.; Kristufek, S. L.; Pan, S.; Richardson, J. J.; Caruso, F., Phenolic Building Blocks for the Assembly of Functional Materials. Angew. Chem., Int. Ed. 2019, 58 (7), 1904-1927.

13. Ejima, H.; Richardson, J. J.; Caruso, F., Metal-phenolic networks as a versatile platform to engineer nanomaterials and biointerfaces. Nano Today 2017, 12, 136-148. 
14. Hao, Y.; Zhang, N.; Luo, J.; Liu, X., Green synthesis of silver nanoparticles by tannic acid with improved catalytic performance towards the reduction of methylene blue. Nano 2018, $13(01), 1850003$.

15. Guo, J.; Ping, Y.; Ejima, H.; Alt, K.; Meissner, M.; Richardson, J. J.; Yan, Y.; Peter, K.; Von Elverfeldt, D.; Hagemeyer, C. E., Engineering multifunctional capsules through the assembly of metal-phenolic networks. Angew. Chem., Int. Ed. 2014, 53 (22), 5546-5551.

16. Amatatongchai, M.; Thimoonnee, S.; Jarujamrus, P.; Nacapricha, D.; Lieberzeit, P. A., Novel amino-containing molecularly-imprinted polymer coating on magnetite-gold core for sensitive and selective carbofuran detection in food. Microchem. J. 2020, 158, 105298.

17. Cai, X.; Li, J.; Zhang, Z.; Yang, F.; Dong, R.; Chen, L., Novel Pb2+ ion imprinted polymers based on ionic interaction via synergy of dual functional monomers for selective solid-phase extraction of $\mathrm{Pb} 2+$ in water samples. ACS Appl. Mater. Interfaces 2014, 6 (1), 305-313.

18. Xu, S.; Chen, L.; Li, J.; Guan, Y.; Lu, H., Novel Hg2+-imprinted polymers based on thymine- $\mathrm{Hg} 2+-$ thymine interaction for highly selective preconcentration of $\mathrm{Hg} 2+$ in water samples. J. Hazard. Mater. 2012, 237, 347-354.

19. Chen, D.; Zhuang, X.; Zhai, J.; Zheng, Y.; Lu, H.; Chen, L., Preparation of highly sensitive Pt nanoparticles-carbon quantum dots/ionic liquid functionalized graphene oxide nanocomposites and application for $\mathrm{H} 2 \mathrm{O} 2$ detection. Sens. Actuators B Chem. 2018, 255, $1500-1506$.

20. Ganrot, P., Metabolism and possible health effects of aluminum. Environ. Health Perspect. 1986, 65, 363-441.

21. Greger, J. L.; Sutherland, J. E.; Yokel, R., Aluminum exposure and metabolism. Crit. Rev. Clin. Lab. Sci. 1997, 34 (5), 439-474. 
22. Exley, C.; House, E. R., Aluminium in the human brain. Monatsh. Chem. 2011, 142 (4), 357-363.

23. Suherman, A. L.; Tanner, E. E.; Kuss, S.; Sokolov, S. V.; Holter, J.; Young, N. P.; Compton, R. G., Voltammetric determination of aluminium (III) at tannic acid capped-gold nanoparticle modified electrodes. Sens. Actuators B Chem. 2018, 265, 682-690.

24. Liu, Y.; Wei, Z.; Duan, W.; Ren, C.; Wu, J.; Liu, D.; Chen, H., A dual-mode sensor for colorimetric and "turn-on" fluorescent detection of ascorbic acid. Dyes and Pigments 2018, 149, 491-497.

25. Barquero, M.; Dominguez, O.; Alonso, M.; Arcos, M., Biosensor for Aluminum (III) Based on a-Chymotrypsin Inhibition using a Disposable Screen-Printed Carbon Electrode and Acetyl-Tyrosine Ethyl Ester as Substrate. Chem. Sci. J. 2015, 6, 89.

26. Barquero-Quirós, M.; Domínguez-Renedo, O.; Alonso-Lomillo, M.; Arcos-Martínez, M., Acetylcholinesterase inhibition-based biosensor for aluminum (III) chronoamperometric determination in aqueous media. Sensors 2014, 14 (5), 8203-8216.

27. Qiong, L.; Lirong, W.; Danli, X.; Guanghan, L., Determination of trace aluminum in foods by stripping voltammetry. Food Chem. 2006, 97 (1), 176-180.

28. Di, J.; Bi, S.; Yang, T.; Zhang, M., Voltammetric determination of aluminum (III) using a reagentless sensor fabricated by sol-gel process. Sens. Actuators B Chem. 2004, 99 (2-3), 468-473.

29. Zhang, F.; Bi, S.; Liu, J.; YANG, X.; WANG, X.; YANG, L.; YU, T.; CHEN, Y.; DAI, L.; YANG, T., Application of dopamine as an electroactive ligand for the determination of aluminum in biological fluids. Anal. Sci. 2002, 18 (3), 293-299.

30. Arancibia, V.; Munoz, C., Determination of aluminium in water samples by adsorptive cathodic stripping voltammetry in the presence of pyrogallol red and a quaternary ammonium salt. Talanta 2007, 73 (3), 546-552. 
31. Santos, L. B.; de Souza, M. T.; Paulino, A. T.; Garcia, E. E.; Nogami, E. M.; Garcia, J. C.; de Souza, N. E., Determination of aluminum in botanical samples by adsorptive cathodic stripping voltammetry as Al-8-hydroxyquinoline complex. Microchem. J. 2014, 112, 50-55. 32. Chang, S.-C., Alizarin Red S modified electrochemical sensors for the detection of aluminum ion. J. Sens. Sci. Technol. 2010, 19 (6), 421-427.

33. Vukomanovic, D. V.; Page, J. A.; Vanloon, G. W., Voltammetric determination of Al (III) with adsorptive preconcentration of the pyrocatechol violet complex. Can. J. Chem. 1991, 69 (9), 1418-1426.

34. Arvand, M.; Kermanian, M.; Zanjanchi, M. A., Direct determination of aluminium in foods and pharmaceutical preparations by potentiometry using an AlMCM-41 modified polymeric membrane sensor. Electrochim. Acta 2010, 55 (23), 6946-6952.

35. Arvand, M.; Kermanian, M., Potentiometric determination of aluminum in foods, pharmaceuticals, and alloys by AlMCM-41-modified carbon paste electrode. Food Anal. Methods 2013, 6 (2), 578-586.

36. Wang, J.; Farias, P. A.; Mahmoud, J. S., Stripping voltammetry of aluminum based on adsorptive accumulation of its solochrome violet RS complex at the static mercury drop electrode. Anal. Chim. Acta 1985, 172, 57-64.

37. Thomas, S. D.; Davey, D. E.; Mulcahy, D. E.; Chow, C. W., Determination of Aluminum by Adsorptive Cathodic Stripping Voltammetry with 1, 2-

Dihydroxyanthraquinone-3-Sulfonic Acid (DASA): Effect of Thin Mercury Film Electrode. Electroanalysis 2006, 18 (22), 2257-2262.

38. See, W. P.; Heng, L. Y.; Nathan, S., Highly sensitive aluminium (III) ion sensor based on a self-assembled monolayer on a gold nanoparticles modified screen-printed carbon electrode. Anal. Sci. 2015, 31 (10), 997-1003. 
39. Watling, K.; Hope, G. A.; Woods, R., SERS Investigation of Gold Dissolution in Chloride and Cyanide Media. J. Electrochem. Soc. 2005, 152 (6), D103.

40. Ahtiainen, R.; Lundström, M., Cyanide-free gold leaching in exceptionally mild chloride solutions. J. Clean. Prod 2019, 234, 9-17.

41. Gan, X.; Liu, T.; Zhong, J.; Liu, X.; Li, G., Effect of silver nanoparticles on the electron transfer reactivity and the catalytic activity of myoglobin. ChemBioChem 2004, 5 (12), 1686-1691.

42. Luo, X.; Morrin, A.; Killard, A. J.; Smyth, M. R., Application of nanoparticles in electrochemical sensors and biosensors. Electroanalysis 2006, 18 (4), 319-326.

43. Liu, T.; Zhong, J.; Gan, X.; Fan, C.; Li, G.; Matsuda, N., Wiring electrons of cytochrome c with silver nanoparticles in layered films. ChemPhysChem 2003, 4 (12), 13641366.

44. Essousi, H.; Barhoumi, H.; Bibani, M.; Ktari, N.; Wendler, F.; Al-Hamry, A.; Kanoun, O., Ion-Imprinted Electrochemical Sensor Based on Copper Nanoparticles-Polyaniline Matrix for Nitrate Detection. J. Sens. 2019, 2019, 4257125.

45. Zhang, L.; Liu, R.; Gung, B. W.; Tindall, S.; Gonzalez, J. M.; Halvorson, J. J.;

Hagerman, A. E., Polyphenol-Aluminum Complex Formation: Implications for Aluminum Tolerance in Plants. J. Agr. Food Chem. 2016, 64 (15), 3025-3033.

46. Ranoszek-Soliwoda, K.; Tomaszewska, E.; Socha, E.; Krzyczmonik, P.; Ignaczak, A.; Orlowski, P.; Krzyzowska, M.; Celichowski, G.; Grobelny, J., The role of tannic acid and sodium citrate in the synthesis of silver nanoparticles. J. Nanopart. Res. 2017, 19 (8), 273. 47. Cao, Y.; Zheng, R.; Ji, X.; Liu, H.; Xie, R.; Yang, W., Syntheses and characterization of nearly monodispersed, size-tunable silver nanoparticles over a wide size range of 7-200 nm by tannic acid reduction. Langmuir 2014, 30 (13), 3876-3882. 
48. Cheng, Y.; Wang, F.; Fang, C.; Su, J.; Yang, L., Preparation and characterization of size and morphology controllable silver nanoparticles by citrate and tannic acid combined reduction at a low temperature. J. Alloys Compd. 2016, 658, 684-688.

49. Ranoszek-Soliwoda, K.; Tomaszewska, E.; Socha, E.; Krzyczmonik, P.; Ignaczak, A.; Orlowski, P.; Krzyzowska, M.; Celichowski, G.; Grobelny, J., The role of tannic acid and sodium citrate in the synthesis of silver nanoparticles. J. Nanoparticle Res. 2017, 19 (8), 273. 50. Lopes, L.; Brito, L. M.; Bezerra, T. T.; Gomes, K. N.; CARVALHO, F. A.; Chaves, M. H.; Cantanhede, W., Silver and gold nanoparticles from tannic acid: synthesis, characterization and evaluation of antileishmanial and cytotoxic activities. An. Acad. Bras. Ciênc. 2018, 90 (3), 2679-2689.

51. Liu, X.; Shao, C.; Chen, T.; He, Z.; Du, G., Stable silver nanoclusters with aggregation-induced emission enhancement for detection of aluminum ion. Sens. Actuators $B$ Chem. 2019, 278, 181-189.

52. Maerten, C.; Lopez, L.; Lupattelli, P.; Rydzek, G.; Pronkin, S.; Schaaf, P.; Jierry, L.; Boulmedais, F., Electrotriggered confined self-assembly of metal-polyphenol nanocoatings using a morphogenic approach. Chem. Mater. 2017, 29 (22), 9668-9679.

53. Krywko-Cendrowska, A., Voltammetric Tracing of Al (III) Using Supramolecular Metal-Polyphenolic Nanofilms Obtained via Electrochemically Assisted Self-Assembly. CHIMIA 2020, 74 (4), 289-292.

54. Zanello, P.; Nervi, C.; De Biani, F. F., Inorganic electrochemistry: theory, practice and application. . RSC Publishing: 2011..

55. Ahmad, M.; Narayanaswamy, R., Fibre optic reflectance sensor for the determination of aluminium (III) in aqueous environment. Anal. Chim. Acta 1994, 291 (3), 255-260. 56. El-Wekil, M. M.; Ali, H. R. H.; Marzouk, A. A.; Ali, R., Synthesis of Fe 3 O 4 nanobead-functionalized 8-hydroxyquinoline sulfonic acid supported by an ion-imprinted 
biopolymer as a recognition site for $\mathrm{Al} 3+$ ions: estimation in human serum and water samples. New J. Chem. 2018, 42 (12), 9828-9836.

57. Ng, S. M.; Narayanaswamy, R., Fluorescence sensor using a molecularly imprinted polymer as a recognition receptor for the detection of aluminium ions in aqueous media. Ann. Clin. Biochem. 2006, 386 (5), 1235-1244.

58. Flowers, P.; Theopold, K.; Langley, R.; Robinson, W., Chemistry 2e. Houston, Texas: OpenStax 2019, 1044-1059.

59. Mizerski, W., Tablice chemiczne, wyd. Adamantan, Warszawa 1997, 69.

60. Zhang, L.; Liu, R.; Gung, B. W.; Tindall, S.; Gonzalez, J. M.; Halvorson, J. J.; Hagerman, A. E., Polyphenol-Aluminum Complex Formation: Implications for Aluminum Tolerance in Plants. J. Agric. Food Chem. 2016, 64 (15), 3025-3033.

61. Briggs, D., Handbook of X-ray Photoelectron Spectroscopy CD Wanger, WM Riggs, LE Davis, JF Moulder and GE Muilenberg Perkin-Elmer Corp., Physical Electronics Division, Eden Prairie, Minnesota, USA, 1979. 190 pp. \$195. Surf. Interface Anal. 1981, 3 (4), v-v.

62. Ivanova, O. S.; Zamborini, F. P., Size-dependent electrochemical oxidation of silver nanoparticles. J. Am. Chem. Soc 2009, 132 (1), 70-72.

63. Saw, E. N.; Grasmik, V.; Rurainsky, C.; Epple, M.; Tschulik, K., Electrochemistry at single bimetallic nanoparticles-using nano impacts for sizing and compositional analysis of individual AgAu alloy nanoparticles. Faraday Discuss. 2016, 193, 327-338.

64. Suherman, A. L.; Tanner, E. E.; Kuss, S.; Sokolov, S. V.; Holter, J.; Young, N. P.; Compton, R. G., Voltammetric determination of aluminium (III) at tannic acid capped-gold nanoparticle modified electrodes. Sens. Actuators B Chem. 2018, 265, 682-690. 
65. Adamczyk, B.; Simon, J.; Kitunen, V.; Adamczyk, S.; Smolander, A., Tannins and their complex interaction with different organic nitrogen compounds and enzymes: old paradigms versus recent advances. ChemistryOpen 2017, 6 (5), 610-614.

66. Amor-Gutiérrez, O.; Rama, E. C.; Fernández-Abedul, M. T.; Costa-García, A., Bioelectroanalysis in a Drop: Construction of a Glucose Biosensor. J. Chem. Educ. 2017, 94 (6), 806-812.

67. Gault, P.; Allen, K.; Newton, K., Plasma aluminium: a redundant test for patients on dialysis? Ann. Clin. Biochem. 2005, 42 (1), 51-54.

68. Shukla, R. P.; Ben-Yoav, H., A Chitosan-Carbon Nanotube-Modified Microelectrode for In Situ Detection of Blood Levels of the Antipsychotic Clozapine in a Finger-Pricked Sample Volume. Adv. Healthcare Mater. 2019, 8 (15), 1900462.

69. Doniach, S.; Sunjic, M., Many-electron singularity in X-ray photoemission and X-ray line spectra from metals. J. Phys. C 1970, 3 (2), 285.

70. Shirley, D. A., High-resolution X-ray photoemission spectrum of the valence bands of gold. Phys. Rev. B 1972, 5 (12), 4709.

71. Hesse, R.; Chassé, T.; Szargan, R., Peak shape analysis of core level photoelectron spectra using UNIFIT for Windows. Fresenius' J. Anal. Chem. 1999, 365 (1-3), 48-54.

72. Scofield, J. H., Hartree-Slater subshell photoionization cross-sections at 1254 and 1487 eV. J. Electron Spectrosc. Relat. Phenom. 1976, 8 (2), 129-137.

73. Jeong, H.-H.; Mark, A. G.; Alarcón-Correa, M.; Kim, I.; Oswald, P.; Lee, T.-C.; Fischer, P., Dispersion and shape engineered plasmonic nanosensors. Nat. Commun. 2016, 7 (1), 11331. 